\title{
Taxonomic revision of the Japanese Tricholoma ustale and closely related species based on molecular phylogenetic and morphological data
}

\author{
Wataru Aoki ${ }^{\mathrm{a}}$, Naoki Endo ${ }^{\mathrm{b}}$, Shuji Ushijima ${ }^{\mathrm{c}}$, Hiroyuki Nagai ${ }^{\mathrm{d}}$, Tetsuro Ito ${ }^{\mathrm{d}}$, Masaki Fukuda ${ }^{\mathrm{a}, \mathrm{e}}$, \\ Akiyoshi Yamada ${ }^{\mathrm{a}, \mathrm{e}, \mathrm{f}, *}$ \\ ${ }^{a}$ Department of Agriculture, Graduate School of Science and Technology, Shinshu University, Minami-minowa, Nagano, 399-4598, Japan \\ ${ }^{b}$ Fungus/Mushroom Resource and Research Center, Faculty of Agriculture, Tottori University, 4-101, Koyama, Tottori, 680-8553, Japan \\ ${ }^{c}$ Tottori, Mycological Institute, 211 Kokooge, Tottori, Tottori, 689-1125, Japan \\ ${ }^{d}$ Faculty of Pharmacy, Gifu University of Medical Science, 4-3-3 Nijigaoka, Kani, Gifu, 509-0293, Japan \\ ${ }^{e}$ Faculty of Agriculture, Shinshu University, Minami-minowa, Nagano, 399-4598, Japan \\ ${ }^{f}$ Institute for Mountain Science, Shinshu University, Minami-minowa, Nagano, 399-4598, Japan
}

\begin{abstract}
"Kakishimeji" identified as Tricholoma ustale and belonging to Tricholoma sect. Genuina is a common poisonous mushroom in Japan. Kakishimeji contains the toxic compound ustalic acid and causes digestive trouble. However, this fungus is consumed in some regions of Japan without any digestive issues. We clarified the probable species complex of Kakishimeji based on a phylogenetic analysis. We collected 89 basidioma specimens of Kakishimeji and related species from various forest sites in Japan and conducted phylogenetic analyses using 7 nuclear and mitochondrial gene sequences. Kakishimeji was found to consist of four distinct phylogenetic clades based on all DNA regions tested. Of these, two clades included European $T$. stans and $T$. albobrunneum type specimens. Another two clades consisted of sister clades to $T$. pessundatum and $T$. ustaloides. In addition, all four phylogenetic clades of Kakishimeji had different spore and basidium sizes. Therefore, we regarded the latter two clades as two new Tricholoma species: T. kakishimeji and T. kakishimejioides.
\end{abstract}

Keywords: cryptic species, ectomycorrhizal fungi, poisonous mushrooms

Article history: Received 15 January 2021, Revised 15 January 2021, Accepted 7 June 2021, Available online 20 September 2021.

\section{Introduction}

"Kakishimeji” has long been identified as Tricholoma ustale (Fr.) P. Kumm. in Japan and belongs to sect. Genuina of the genus Tricholoma (Kawamura, 1925, 1929; Imazeki \& Hongo, 1987; Heilmann-Clausen, Christensen, Frøslev, \& Kjøller, 2017). Sect. Genui$n a$ is defined by a reddish brown pileus and is commonly known as "burnt knight" in the United Kingdom (Christensen \& Heilmann-Clausen, 2013). Kakishimeji was first identified as T. ustale Fr. in Japan by Kawamura (1925) and was morphologically described as T. ustale Fr. (= T. ustale (Fr.) P. Kumm.) by Kawamura (1929), based on a specimen collected at the foot of Mt. Iizuna-yama, Nagano Prefecture. Imai (1938) described two similar species in the sect. Genuina, i.e., "Matsushimeji" identified as T. albobrunneum (Pers. ex Fr.) Quél. (= T. albobrunneum (Pers.) P. Kumm.) and "Ookakishimeji" identified as T. pessundatum (Fr.) Quél.; both were based on specimens sampled mostly in Hokkaido, Japan. Imazeki (1942) reported Matsushimeji as a poisonous mushroom.

* Corresponding author.

Institute for Mountain Science, Shinshu University, Minami-minowa, Nagano, 3994598, Japan.

E-mail address: akiyosh@shinshu-u.ac.jp (A. Yamada)
Kakishimeji and Matsushimeji were often confused in their identifications and conspecificity due to their close resemblance in morphology and ecology (Imazeki \& Hongo, 1957, 1965, 1987). Ookakishimeji has limited reports lately (Ito, 1959). Matsuda and Hongo (1962) described T. maculatipus with the common name "Azashimeji" collected in Sandankyo, Hiroshima Prefecture and Oguni, Yamagata Prefecture. Another three closely related species to Kakishimeji in the sect. Genuina known from Japan are Murewashimeji, identified as T. populinum J. E. Lange (Murata, 1978), Nigashimeji and Kakishimeji-modoki, both identified as T. ustaloides Romagn. (Ikeda, 2005; Miyauchi, 2010), and Matsubarashimeji, identified as T. stans (Fr.) Sacc. (Miyauchi, 2010).

Kakishimeji has long been recognized as a poisonous mushroom in Japan (Ichioka, 1799). Although Kawamura (1925) described Kakishimeji as poisonous, Kawamura (1931) described its edibility as uncertain. Hiroe (1949) described Kakishimeji as edible, especially in the basidiomata harvested under seaside pine forests, and salting was recommended for safe use because boiling occasionally causes stomach trouble. Imazeki and Hongo (1965) described Kakishimeji as slightly poisonous. Later publications regarded Kakishimeji as a distinct poisonous mushroom (Imazeki, Hongo, \& Tubaki, 1970; Imazeki \& Hongo, 1987; Yamashita \& Furukawa, 
1993; Hongo, 1994; Ikeda, 2005; Nagasawa, 2009). In Europe, T. ustale is described as edible after removing its bitter taste by boiling (Romagnesi, 1971), inedible (Breitenbach \& Kränzlin, 1991) or as poisonous (Phillips, 1981). The causal toxic compound of Kakishimeji, ustalic acid, was identified (Sano et al., 2002). Ustalic acid inhibits $\mathrm{Na}^{+} / \mathrm{K}^{+}$-ATPase purified from porcine cerebral cortex and its crude enzyme extracted from mouse intestinal mucosal cells (Hayakawa, Watanabe, \& Kigoshi, 2008), thereby causing digestive troubles such as stomachache, vomiting, and diarrhea in human. In 2000-2015, 18 incidents of, and 61 persons suffering from, stomach troubles after eating Kakishimeji were reported (Ministry of Health, Labor and Welfare; https://www.mhlw.go.jp/stf/seisakunitsuite/bunya/0000142705.html). This fungus causes one third of mushroom poisoning cases in Japan.

Tricholoma ustale (Fr.) P. Kumm. was described as Agaricus ustalis Fr. collected near Germany (Fries, 1818). Afterwards, it was moved to genus Tricholoma (Kummer, 1871). The morphological characteristics of Japanese T. ustale named Kakishimeji described by Kawamura (1929) are as follows: pileus 3-8 cm diam, first convex, later plane, reddish brown, pale to margin, glabrous, viscid in moist; flesh white and sinuate; stipe cylindrical to tapering upwards, surface pale reddish brown, hollow to medulla; gill white, frequently brown spot, sinuate; spore 4-6 $\times 3-4 \mu \mathrm{m}$ in length, one oily droplet; taste bitter; grows in forest and fruits in autumn. Other Japanese species closely related to Kakishimeji in the sect. Genuina as mentioned above are characterized comparatively with Kakishimeji, because Kakishimeji is quite commonly sampled, but the others have a limited record of samples (Table 1).

Genus Tricholoma including Kakishimeji is an ectomycorrhizal taxon (Trappe, 1962; Miller, Koo, \& Molina, 1991; Agerer, 19872008). In fact, cultured strain AT610 of Kakishimeji (identified as T. ustale) reportedly showed in vitro ectomycorrhization with Pinus densiflora host (Yamada et al., 2010). However, there are limited data on the ectomycorrhizal associations in Tricholoma, particularly sect. Genuina (Agerer, 1987-2008; Duñabeitia, Hormilla, Salcedo, \& Peña, 1996; Yamada, Kanekawa, \& Ohmasa, 1999; Yamada, Ogura, \& Ohmasa, 2001; Lefevre, 2002; Endo et al., 2015). Further investigation of those ectomycorrhizae, especially in terms of the host relationships, will illuminate the taxonomy of Kakishimeji and its closely related species in sect. Genuina.

Here, we revised the taxonomic position of Kakishimeji and closely related species in sect. Genuina sampled in Japan, based on multi-gene molecular phylogenetic analyses, as has been reported for genus Tricholoma in diverse geographic regions (e.g., Grubisha, Levsen, Olson, \& Taylor, 2012; Halama, Wany, Czosnykowska-Łukacka, \& Dobosz, 2016; Heilmann-Clausen et al., 2017; Reschke, Popa, Yang, \& Kost, 2018). Our hypothesis is that there is taxonomic confusion regarding the poisonous Kakishimeji and closely related species, which has long hampered discussion of the edibility and toxicity of these mushroom species.

\section{Materials and Methods}

\section{2-1. Specimens examined}

Eighty-nine basidioma specimens (Table 1) were collected from various forest sites in Japan from 2000 to 2019. They were lyophilized, oven-dried at $60{ }^{\circ} \mathrm{C}$ overnight to inactivate DNases and other oxidative enzymes, and stored in the laboratory. Where necessary, specimens were deposited in the National Museum of Nature and Science (TNS). We recorded the macroscopic characteristics, such as shape, size, color and texture, of the specimens. In addition, seven specimens from the Mycological Herbarium, Totto- ri University (TUMH), nine from Tottori Mycological Institute (TMI), eight from TNS, and eight from Osaka Museum of Natural History (OMNH) were borrowed and studied (Table 1).

Fresh basidiomata sampled in 2018-2019 were tested using guaiac reagent (Clémençon, 2009); 1 g guaiac resin (Nacalai Tesque, Kyoto) was dissolved in $50 \mathrm{~mL} \mathrm{70 \%} \mathrm{ethanol,} \mathrm{and} \mathrm{the} \mathrm{pre-}$ pared reagent was used within 3 mo. Three to four drops of the reagent were applied to sectioned basidiomata, and the positive (blue color)/negative (brown color) reaction was recorded at $5 \mathrm{~min}$.

\section{2-2. Microscopic observation of selected specimens}

Dried material was rehydrated in a drop of $70 \%$ ethanol and then in distilled water for $1 \mathrm{~h}$. Fully rehydrated samples were mounted using lactic acid on a glass slide and observed under a differential interference contrast microscope (AXIO Imager A1, Carl Zeiss, Göttingen, Germany). We observed the sizes of the basidiospore, basidium, sterigma, pileipellis, stipitipellis, and trama (Clémençon, 2012). Melzer's reagent was added to the spores and basidia (Clémençon, 2012). The Q-value (length/width) of each spore was calculated. Fifty cells in each structure and specimen were measured for length and width. Numerical data were subjected to one-way analysis of variance using $\mathrm{R}$ (https://www.r-project. org/), and the significance of differences was determined by Tukey's post hoc test $(P<0.05)$. For the morphological definition of Kakishimeji (= Tricholoma ustale sensu Kawamura), we followed Kawamura (1929).

\section{2-3. DNA analysis}

DNA was extracted from dried basidioma specimens as described by Gardes and Bruns (1993) with minor modifications. For PCR, we focused on multiple genes: the internal transcribed spacer (ITS) and intergenic spacer 1 (IGS1) regions of the nuclear ribosomal RNA gene (nrDNA), tef-1, gapdh, rpb2, small subunit of the mitochondrial ribosomal RNA gene (mtSSU), and atp6. The primers are listed in Table 2. PCR was conducted using the GeneAmp PCR System 2700 (Applied Biosystems, Foster City, CA). The $25 \mu \mathrm{L}$ PCR mixture consisted of $2.5 \mu \mathrm{L} 10 \times$ DreamTaq buffer, $2.5 \mu \mathrm{L} 0.2$ mM dNTP mixture, $2.5 \mu \mathrm{L} 0.5 \mu \mathrm{M}$ each primer, $0.125 \mu \mathrm{L} 0.625 \mathrm{U}$ DreamTaq DNA Polymerase (Thermo Fisher Scientific, Waltham, MA) and $0.5 \mu \mathrm{L}$ extracted DNA solution. The PCR cycle parameters were initial denaturation at $95^{\circ} \mathrm{C}$ for $3 \mathrm{~min}$, followed by 35 cycles of denaturation at $95^{\circ} \mathrm{C}$ for $30 \mathrm{~s}$, annealing at $46-55^{\circ} \mathrm{C}$ for $30 \mathrm{~s}$, and extension at $72{ }^{\circ} \mathrm{C}$ for $1.5 \mathrm{~min}$, and a final extension step at $72{ }^{\circ} \mathrm{C}$ for $10 \mathrm{~min}$. The PCR products were electrophoresed (Mupid"-exU; TaKaRa Bio, Kusatsu, Japan) on a 1.5\% agarose gel (Agarose for $\geqq 1$ $\mathrm{kb}$ fragments, 01163-76, Nacalai Tesque, Kyoto, Japan) for $30 \mathrm{~min}$, stained with $0.001 \%$ ethidium bromide solution, and visualized using an ultraviolet illuminator (NM-15; UVP, Upland, CA). The PCR products were purified using the QIAquick PCR Purification Kit (QIAGEN, Venlo, the Netherlands) and subjected to cycle sequencing. The ITS and IGS1 regions of nrDNA, gapdh, and the $\mathrm{mtSSU}$ were cloned manually before cycle sequencing using the Mighty TA-Cloning Kit (TaKaRa Bio) and then inserted into competent Escherichia coli JM109 cells (TaKaRa Bio).

For cycle sequencing, the $10 \mu \mathrm{L}$ reaction mixture consisted of 2 $\mu \mathrm{L}$ distilled water, $2 \mu \mathrm{L} 10 \times$ buffer, $1 \mu \mathrm{L} 5 \mathrm{mM}$ primer, $1 \mu \mathrm{L}$ Ready Reaction Mix (BigDye Terminator v. 3.1 Cycle Sequencing Kit, Thermo Fisher Scientific), and $4 \mu \mathrm{L}$ purified DNA. The PCR conditions for cycle sequencing were initial denaturation at $96{ }^{\circ} \mathrm{C}$ for 1 min, followed by 25 cycles of denaturation at $96^{\circ} \mathrm{C}$ for $10 \mathrm{~s}$, annealing at $46-55^{\circ} \mathrm{C}$ (Table 2) for $5 \mathrm{~s}$, and extension at $60^{\circ} \mathrm{C}$ for $4 \mathrm{~min}$. 
Table 1 Tricholoma specimens referred to Kakishimeji and used for this study.

\begin{tabular}{|c|c|c|c|c|c|}
\hline \multirow[b]{2}{*}{ Species } & \multirow[b]{2}{*}{ Specimen ID } & \multicolumn{3}{|c|}{ Sampling data of basidioma specimen } & \multirow{2}{*}{$\begin{array}{l}\text { Status of } \\
\text { specimen }^{2}\end{array}$} \\
\hline & & $\begin{array}{c}\text { Date } \\
(\mathrm{Y} / \mathrm{M} / \mathrm{D})\end{array}$ & $\begin{array}{c}\text { Site } \\
\text { (Site, Municipal area, Prefecture) }\end{array}$ & $\begin{array}{l}\text { Canopy } \\
\text { tree }^{1}\end{array}$ & \\
\hline \multicolumn{6}{|l|}{ (Kakishimeji-like, section Genuina) } \\
\hline T. ustale ("Kakishimeji") & AT612 $^{*}(=$ NBRC 33141; TNS-F41488) & $1997 / 11 / 4$ & Naka, Hitachi-ohmiya, Ibaraki & $\mathrm{Pd}$ & $\mathrm{C}$ \\
\hline T. ustale ("Kakishimeji”) & $\begin{array}{l}\text { AT610 }^{*}(=N B R C \text { 33139, ATCC MYA-922; } \\
\text { TNS-F11550) }\end{array}$ & $1997 / 11 / 21$ & Naka, Hitachi-ohmiya, Ibaraki & $\mathrm{Pd}$ & $\mathrm{C}$ \\
\hline T. ustale ("Kakishimeji”) & TUA- 67,68 & $2018 / 10 / 8$ & Mt. Madarao-san, Nakano, Nagano & $\mathrm{Fc}$ & $\mathrm{D}$ \\
\hline T. ustale ("Kakishimeji") & AY 2101103-001 (TUA-19) & $2010 / 11 / 3$ & Mt. Reisenji-san, Shinano, Nagano & Qs & $\mathrm{D}$ \\
\hline T. ustale ("Kakishimeji") & TUA-75 & 2018/10/17 & Mt. Iizuna-yama, Iizuna, Nagano & $\mathrm{Pa}$ & $\mathrm{F}+\mathrm{D}$ \\
\hline T. ustale ("Kakishimeji”) & TUA-76, 77 & $2018 / 10 / 17$ & Mt. Iizuna-yama, Iizuna, Nagano & Qs & $\mathrm{D}$ \\
\hline T. ustale ("Kakishimeji”) & TUA-78 & $2018 / 10 / 17$ & Mt. Iizuna-yama, Iizuna, Nagano & $\mathrm{Pd}$ & $\mathrm{F}+\mathrm{D}$ \\
\hline T. ustale ("Kakishimeji") & TUA-126 & $2019 / 11 / 8$ & Mt. Iizuna-yama, Iizuna, Nagano & Qs & $\mathrm{D}$ \\
\hline T. ustale ("Kakishimeji") & OMNH 2802 & $1963 / 10 / 7$ & Hasuike Pond, Yamanouchi, Nagano & ND & $\mathrm{D}$ \\
\hline T. ustale ("Kakishimeji”) & TUA-38 & $2018 / 9 / 20$ & Mt. Norikura-dake, Matsumoto, Nagano & Qc & $\mathrm{F}+\mathrm{D}$ \\
\hline T. ustale ("Kakishimeji”) & TUA-40 & $2018 / 9 / 20$ & Mt. Norikura-dake, Matsumoto, Nagano & $\mathrm{Td}$ & $\mathrm{D}$ \\
\hline T. ustale ("Kakishimeji") & TUA-58 & $2018 / 10 / 2$ & Mt. Norikura-dake, Matsumoto, Nagano & $\mathrm{Td}$ & $\mathrm{D}$ \\
\hline T. ustale ("Kakishimeji") & TUA-59-61, 63-65 & $2018 / 10 / 2$ & Mt. Norikura-dake, Matsumoto, Nagano & Qc & $\mathrm{F}+\mathrm{D}$ \\
\hline T. ustale ("Kakishimeji") & TUA-62 & $2018 / 10 / 2$ & Mt. Norikura-dake, Matsumoto, Nagano & $\mathrm{Td}$ & $\mathrm{F}+\mathrm{D}$ \\
\hline T. ustale ("Kakishimeji”) & TUA-113, 114 & $2019 / 10 / 10$ & Mt. Norikura-dake, Matsumoto, Nagano & $\mathrm{Td}$ & $\mathrm{F}+\mathrm{D}$ \\
\hline T. ustale ("Kakishimeji") & TUA-96 & $2019 / 9 / 26$ & Mt. Tateshina-yama, Saku, Nagano & $\mathrm{Td}, \mathrm{Av}$ & $\mathrm{F}+\mathrm{D}$ \\
\hline T. ustale ("Kakishimeji") & TUA-101-105 & $2019 / 10 / 3$ & Mt. Yatsugatake, Koumi, Nagano & $\mathrm{Td}$ & $\mathrm{F}+\mathrm{D}$ \\
\hline T. ustale ("Kakishimeji”) & TUA-35 & $2018 / 9 / 14$ & Juumonji-touge Pass, Kawakami, Nagano & $\mathrm{Td}$ & $\mathrm{D}$ \\
\hline T. ustale ("Kakishimeji”) & TUA-41 & $2018 / 9 / 20$ & Juumonji-touge Pass, Kawakami, Nagano & $\mathrm{Td}$ & $\mathrm{D}$ \\
\hline T. ustale ("Kakishimeji") & TUA-42-46 & $2018 / 9 / 25$ & Juumonji-touge Pass, Kawakami, Nagano & $\mathrm{Td}$ & $\mathrm{D}$ \\
\hline T. ustale ("Kakishimeji") & TUA-106, 107 & $2019 / 10 / 3$ & Juumonji-touge Pass, Kawakami, Nagano & $\mathrm{Td}$ & $\mathrm{D}$ \\
\hline T. ustale ("Kakishimeji”) & TUA-71 & $2018 / 10 / 14$ & Yokokawa, Tatsuno, Nagano & Qs & $\mathrm{F}+\mathrm{D}$ \\
\hline T. ustale ("Kakishimeji”) & AY 2001029-001 (TUA-6) & $2000 / 10 / 29$ & Orikusa-touge Pass, Nakagawa, Nagano & Qs & $\mathrm{D}$ \\
\hline T. ustale ("Kakishimeji") & TUA-70 & $2018 / 10 / 10$ & Orikusa-touge Pass, Nakagawa, Nagano & Qs, Pd & $\mathrm{D}$ \\
\hline T. ustale ("Kakishimeji”) & TUA-74 & $2018 / 10 / 16$ & Orikusa-touge Pass, Nakagawa, Nagano & Qs & $\mathrm{D}$ \\
\hline T. ustale ("Kakishimeji”) & TUA-118, 119 & $2019 / 10 / 30$ & Kuwahara, Nakagawa, Nagano & $\mathrm{Pd}$ & $\mathrm{F}+\mathrm{D}$ \\
\hline T. ustale ("Kakishimeji”) & TUA-66 & $2018 / 10 / 5$ & Tajima-zawa, Nakagawa, Nagano & Qa & $\mathrm{F}, \mathrm{D}$ \\
\hline T. ustale ("Kakishimeji") & TUA-72 & $2018 / 10 / 16$ & Tajima-zawa, Nakagawa, Nagano & Qa & $\mathrm{D}$ \\
\hline T. ustale ("Kakishimeji") & AY 2001027-001 (TUA-8) & $2000 / 10 / 27$ & Koshibu, Matsukawa, Nagano & ND & $\mathrm{D}$ \\
\hline T. ustale ("Kakishimeji") & AY 2001029-001 (TUA-9) & $2000 / 10 / 29$ & Koshibu, Matsukawa, Nagano & ND & $\mathrm{D}$ \\
\hline T. ustale ("Kakishimeji”) & TUA-69 & $2018 / 10 / 10$ & Shoubu-zawa, Ooshika, Nagano & Ts & $\mathrm{D}$ \\
\hline T. ustale ("Kakishimeji") & TUA-73 & $2018 / 10 / 16$ & Shoubu-zawa, Ooshika, Nagano & Ts & $\mathrm{D}$ \\
\hline T. ustale ("Kakishimeji”) & TUA-117 & $2019 / 10 / 30$ & Shoubu-zawa, Ooshika, Nagano & Ts & $\mathrm{D}$ \\
\hline T. ustale ("Kakishimeji”) & AY 2070706-001 (TUA-4) & $2007 / 6 / 28$ & Toyooka, Nagano & $\mathrm{Pd}$ & $\mathrm{D}$ \\
\hline T. ustale ("Kakishimeji”) & TUA-79 & $2018 / 10 / 31$ & Misakubo, Hamamatsu, Shizuoka & $\mathrm{Pd}$ & $\mathrm{D}$ \\
\hline T. ustale ("Kakishimeji") & OMNH 1938 & $1958 / 10 / 24$ & Ishiyama-sotohata, Otsu, Shiga & ND & $\mathrm{D}$ \\
\hline T. ustale ("Kakishimeji") & OMNH 1947 & $1958 / 10 / 30$ & Sato, Otsu, Shiga & ND & $\mathrm{D}$ \\
\hline T. ustale ("Kakishimeji”) & OMNH 3008 & $1964 / 10 / 31$ & Senchou, Otsu, Shiga & ND & $\mathrm{D}$ \\
\hline T. ustale ("Kakishimeji") & OMNH 3606 & $1967 / 11 / 9$ & Otsu, Shiga & ND & $\mathrm{D}$ \\
\hline T. ustale ("Kakishimeji") & TaY20191104-101 & $2019 / 11 / 4$ & Kashihara Shrine, Kashihara, Nara & $\mathrm{Cc}, \mathrm{Qg}$ & $\mathrm{F}+\mathrm{D}$ \\
\hline T. ustale ("Kakishimeji”) & TUA-81 & $2018 / 12 / 26$ & Wakayama & $\mathrm{Pd}$ & $\mathrm{D}$ \\
\hline T. ustale ("Kakishimeji”) & TUA-127 & $2019 / 11 / 13$ & Tottori Sand Dune, Tottori, Tottori & $\mathrm{Pt}$ & $\mathrm{F}+\mathrm{D}$ \\
\hline T. ustale ("Kakishimeji”) & TUA-143 & $2019 / 11 / 14$ & Tottori Sand Dune, Tottori, Tottori & $\mathrm{Pt}$ & $\mathrm{D}$ \\
\hline T. ustale ("Kakishimeji") & TUMH 62876 & 2016/11/12 & Kokufu, Tottori, Tottori & Qg, Qm & $\mathrm{D}$ \\
\hline T. ustale ("Kakishimeji") & TUA-134 & $2019 / 11 / 13$ & Kokufu, Tottori, Tottori & Qg, Qm & $\mathrm{F}+\mathrm{D}$ \\
\hline T. ustale ("Kakishimeji") & TUA-138, 141, 142 & $2019 / 11 / 13$ & Kokufu, Tottori, Tottori & Qg & $\mathrm{D}$ \\
\hline T. ustale ("Kakishimeji”) & TUMH 62707 & $2016 / 12 / 16$ & Hamasaka, Tottori, Tottori & $\mathrm{Pt}$ & $\mathrm{D}$ \\
\hline T. ustale ("Kakishimeji”) & TUA-128 & $2019 / 11 / 13$ & Hamasaka, Tottori, Tottori & $\mathrm{Pt}$ & $\mathrm{F}+\mathrm{D}$ \\
\hline T. ustale ("Kakishimeji”) & TUA-129-132 & $2019 / 11 / 13$ & Hamasaka, Tottori, Tottori & $\mathrm{Pt}$ & $\mathrm{D}$ \\
\hline T. ustale ("Kakishimeji”) & TUMH 62228 & $2015 / 11 / 24$ & Ooike Pond, Tottori, Tottori & Qg, Qm & $\mathrm{D}$ \\
\hline T. ustale ("Kakishimeji") & TUA-133, 134, 136, 137 & $2019 / 11 / 13$ & Ooike Pond, Tottori, Tottori & $\mathrm{Qg}, \mathrm{Qm}$ & $\mathrm{F}+\mathrm{D}$ \\
\hline T. ustale ("Kakishimeji") & TUA-140, 145 & $2019 / 11 / 13$ & Fuse, Tottori, Tottori & Qa & $\mathrm{D}$ \\
\hline T. ustale ("Kakishimeji") & TUMH 62875 & $2016 / 11 / 3$ & Makibara, Tottori, Tottori & $\mathrm{F}$ & $\mathrm{F}+\mathrm{D}$ \\
\hline T. ustale ("Kakishimeji”) & OMNH 1756 & $1958 / 4 / 13$ & Hitotsuba, Miyazaki, Miyazaki & ND & $\mathrm{D}$ \\
\hline T. ustale ("Kakishimeji") & TUMH 61677 & $2013 / 11 / 23$ & Nishifumoto, Takaharu, Miyazaki & $\mathrm{F}$ & $\mathrm{D}$ \\
\hline T. albobrunneum ("Matsushimeji") & TMI 5588 & $1938 / 10 / 8$ & Ishikari, Sapporo, Hokkaido & ND & $\mathrm{D}$ \\
\hline T. albobrunneum ("Matsushimeji”) & TMI Fukuti 6 & $\begin{array}{l}\text { (estim a ted } \\
\text { 1930s) }\end{array}$ & Ishikari, Hokkaido & ND & $\mathrm{D}$ \\
\hline T. albobrunneum ("Matsushimeji”) & TMI Fukuroda 52 & $1937 / 10 / 11$ & Fukuroda, Daigo, Ibaraki & ND & $\mathrm{D}$ \\
\hline T. albobrunneum ("Matsushimeji") & TMI Mizu 5 & $1940 / 9 / 27$ & Mt. Mizugaki-yama, Hokuto, Yamanashi & ND & $\mathrm{D}$ \\
\hline T. albobrunneum ("Matsushimeji") & TMI 12A, 12B & $1940 / 10$ & Narusawa, Yamanashi & ND & $\mathrm{D}$ \\
\hline T. albobrunneum ("Matsushimeji") & TaY20181117-001 & 2018/11/17 & Tottori Sand Dunes, Tottori, Tottori & $\mathrm{Pt}$ & $\mathrm{D}$ \\
\hline T. stans ("Matsubarashimeji”) & TUMH 62879 & 2016/12/16 & Hamasaka, Tottori, Tottori & $\mathrm{Pt}$ & $\mathrm{D}$ \\
\hline T. pessundatum (“Ookakishimeji”) & TMI 5615 & $1934 / 10 / 8$ & Sapporo, Hokkaido (market) & ND & $\mathrm{D}$ \\
\hline T. pessundatum ("Ookakishimeji”) & TMI 5614 & $1933 / 10 / 8$ & Jozankei, Sapporo, Hokkaido & ND & $\mathrm{D}$ \\
\hline
\end{tabular}




\begin{tabular}{|c|c|c|c|c|c|}
\hline \multirow[b]{2}{*}{ Species } & \multirow[b]{2}{*}{ Specimen ID } & \multicolumn{3}{|c|}{ Sampling data of basidioma specimen } & \multirow{2}{*}{$\begin{array}{l}\text { Status of } \\
\text { specimen }^{2}\end{array}$} \\
\hline & & $\begin{array}{c}\text { Date } \\
(\mathrm{Y} / \mathrm{M} / \mathrm{D})\end{array}$ & $\begin{array}{c}\text { Site } \\
\text { (Site, Municipal area, Prefecture) }\end{array}$ & $\begin{array}{l}\text { Canopy } \\
\text { tree }^{1}\end{array}$ & \\
\hline T. pessundatum (“Ookakishimeji”) & TMI 25 & $1940 / 10 / 4$ & Saiko Lake, Fuji-kawaguchiko, Yamanashi & ND & $\mathrm{D}$ \\
\hline T. pessundatum ("Ookakishimeji”) & TUMH 63117 & $2017 / 11 / 16$ & Ooike Pond, Tottori, Tottori & Qg, Qm & $\mathrm{D}$ \\
\hline T. ustaloides ("Nigashimeji") & TNS-F18995 & $1975 / 10 / 14$ & Kashiwagi, Noto, Ishikawa & Qs & $\mathrm{D}$ \\
\hline T. ustaloides ("Nigashimeji") & TNS-F18996 & $1978 / 10 / 14$ & Kunishige, Noto, Ishikawa & Pd, F & $\mathrm{D}$ \\
\hline T. ustaloides ("Nigashimeji") & TNS-F18997 & $1985 / 10 / 19$ & Akiyoshi, Noto, Ishikawa & $\mathrm{Pd}$ & $\mathrm{D}$ \\
\hline T. ustaloides ("Nigashimeji") & TNS-F18999 & $1994 / 10 / 9$ & Matsunami, Noto, Ishikawa & Pd, F & $\mathrm{D}$ \\
\hline T. ustaloides ("Nigashimeji") & TNS-F18998 & $1986 / 10 / 10$ & Ohara, Kanazawa, Ishikawa & Pd, F & $\mathrm{D}$ \\
\hline T. ustaloides ("Nigashimeji") & TNS-F19000 & $2002 / 10 / 27$ & Tatsunokuchi, Nomi, Ishikawa & Pd, F & $\mathrm{D}$ \\
\hline T. ustaloides ("Nigashimeji") & TNS-F38557 & $2008 / 10 / 11$ & Kamiwasumi, Noto, Ishikawa & Pd, F & $\mathrm{D}$ \\
\hline T. ustaloides ("Nigashimeji") & TNS-F38558 & $2010 / 10 / 24$ & Shichikuro, Tsubata, Ishikawa & Pd, F & $\mathrm{D}$ \\
\hline T. maculatipus (“Azashimeji”) & OMNH 2392 & $1961 / 10 / 22$ & Awanoyu-onsen, Oguni, Yamagata & $\mathrm{Fc}$ & $\mathrm{D}$ \\
\hline T. maculatipus ("Azashimeji”) & OMNH 3162 & $1965 / 10 / 2$ & Yonezawa, Yamagata & ND & $\mathrm{D}$ \\
\hline Tricholoma sp. ("Kakishimeji-like") & AY2080904-001, 002 (TUA-1, 2) & $2008 / 9 / 4$ & Mt. Rishiri-dake, Rishiri, Hokkaido & $\mathrm{Pp}$ & $\mathrm{D}$ \\
\hline Tricholoma sp. ("Kakishimeji-like") & AY2161105-001 (TUA-18) & $2016 / 11 / 5$ & Shimokita-hantou Peninsula, Mutsu, Aomori & $\mathrm{Pd}$ & $\mathrm{D}$ \\
\hline Tricholoma sp. ("Kakishimeji-like") & AY2111014-001 (TUA-17) & $2011 / 10 / 14$ & Asahi, Matsumoto, Nagano & $\mathrm{Pa}$ & $\mathrm{D}$ \\
\hline Tricholoma sp. ("Kakishimeji-like") & TUA-125 & $2019 / 11 / 5$ & Asahi, Matsumoto, Nagano & $\mathrm{Pd}$ & $\mathrm{F}+\mathrm{D}$ \\
\hline Tricholoma sp. ("Kakishimeji-like") & TUA-95 & $2019 / 9 / 20$ & Orikusa-touge Pass, Nakagawa, Nagano & $\mathrm{Fj}$ & $\mathrm{D}$ \\
\hline $\begin{array}{l}\text { Tricholoma sp. ("Kakishimeji-like") } \\
\text { (not Kakishimeji-like, section Genuina }\end{array}$ & TUA-48 & $2018 / 9 / 26$ & Tajima-zawa, Nakagawa, Nagano & Qs, Qa & $\mathrm{D}$ \\
\hline T. japonicum & AY2101020-001, 002 (TUA-20, 21) & $2010 / 10 / 20$ & Kuwahara, Nakagawa, Nagano & Qs, Qa, Pd & $\mathrm{D}$ \\
\hline T. japonicum & AY2001029-001 (TUA-10) & $2000 / 10 / 29$ & Koshibu, Nakagawa, Nagano & ND & $\mathrm{D}$ \\
\hline T. japonicum & AY2001102-001 (TUA-11) & $2000 / 11 / 2$ & Koshibu, Matsukawa, Nagano & ND & $\mathrm{D}$ \\
\hline T. imbricatum & AY2011020-001 (TUA-5) & $2001 / 10 / 20$ & Kuwahara, Nakagawa, Nagano & $\mathrm{Pd}$ & $\mathrm{D}$ \\
\hline $\begin{array}{l}\text { T. aff. acerbum } \\
\text { (Section Caligata) }\end{array}$ & AY2000925-001 (TUA-14) & $2000 / 9 / 25$ & Ibaraki & ND & $\mathrm{D}$ \\
\hline $\begin{array}{l}\text { T. matsutake } \\
\text { (Section Tricholoma) }\end{array}$ & TUA-84 & $2018 / 10 / 10$ & Sekizawa, Shiojiri, Nagano & Ts & $\mathrm{D}$ \\
\hline T. flavovirens & AY1970920-001 (TUA-15) & $1997 / 9 / 20$ & Naka, Hitachi-ohmiya, Ibaraki & $\mathrm{Pd}$ & $\mathrm{D}$ \\
\hline
\end{tabular}

"Cultures isolate established from basidioma tissue.

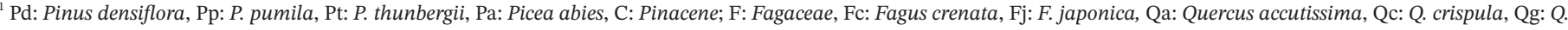
glauca, Qm: Q. myrsinifolia Qs: Q. serrata, Cc: Castanopsis sieboldii, Td: Tsuga diversifolia, Ts: T. siebordii Av: Abies veitchii, ND: No description.

${ }^{2} \mathrm{D}$ : Dried basidioma specimen was observed, F+D: Both fresh and dried basidioma specimens were observed, C: Cultured mycelium was observed.

Table 2 PCR primers used in the present study.

\begin{tabular}{|c|c|c|c|}
\hline $\begin{array}{l}\text { Targeted } \\
\text { region }\end{array}$ & Name & Sequence $\left(5^{\prime} \rightarrow 3^{\prime}\right)$ & $\begin{array}{c}\text { Tm value } \\
\left({ }^{\circ} \mathrm{C}\right)\end{array}$ \\
\hline \multirow{2}{*}{$\begin{array}{l}\text { ITS of } \\
\text { nrDNA }\end{array}$} & $\operatorname{ITS} 1 F(F)^{1}$ & CTTGGTCATTTAGAGGAAGTAA & 55 \\
\hline & ITS4 $(\mathrm{R})^{2}$ & TCCTCCGCTTATTGATATGC & 60 \\
\hline \multirow{2}{*}{$\begin{array}{l}\text { IGS1 of } \\
\text { nrDNA }\end{array}$} & $\operatorname{CNL} 12(\mathrm{~F})^{3}$ & CTGAACGCCTCTAAGTCAG & 56 \\
\hline & 5S-Anderson $(\mathrm{R})^{4}$ & CAGAGTCCTATGGCCGTGGAT & 66 \\
\hline \multirow{2}{*}{ rpb2 } & rpb2_tu_f1 (F) ${ }^{5}$ & CTGTCGGYTCYTATTCTGC & 53 \\
\hline & rpb2_tu_r1 (R) ${ }^{5}$ & GCTRGGATGAATCTCACAATG & 52 \\
\hline \multirow{2}{*}{ gapdh } & gpd_tu_f1 $(\mathrm{F})^{5}$ & ATGTTGTTGTTGACGCTA & 49 \\
\hline & gpd_tu_r1 $(\mathrm{R})^{5}$ & AGGTCTACATGTTYAARTACG & 52 \\
\hline \multirow{2}{*}{ tef-1 } & tef_tu_f1 $(\mathrm{F})^{5}$ & GTGAACAAGATGGACACYAC & 53 \\
\hline & tef_tu_r1 $(\mathrm{R})^{5}$ & GACAACGTYGGYTTCAAC & 51 \\
\hline \multirow{2}{*}{$\begin{array}{l}\text { SSU of } \\
\text { mtrDNA }\end{array}$} & $\operatorname{MS1}(\mathrm{F})^{2}$ & CAGCAGTCAAGAATATTAGTCAATG & 52 \\
\hline & $\operatorname{MS} 2(R)^{2}$ & GCGGATTATCGAATTAAATAAC & 48 \\
\hline \multirow{2}{*}{ atp6 } & $\operatorname{ATP}-3 f(F)^{6}$ & TCTCCTTTAGAACAATTTGA & 46 \\
\hline & ATP-6r $(\mathrm{R})^{7}$ & AACTAATARAGGAACTAAAGCTA & 48 \\
\hline
\end{tabular}

${ }^{1}$ Gardes and Bruns (1993), ${ }^{2}$ White et al. (1990), ${ }^{3}$ Anderson and Stasovski (1992), ${ }^{4}$ Henrion et al. (1992), ${ }^{5}$ Designed in this study, ${ }^{6}$ Kretzer and Bruns (1999), ${ }^{7}$ Binder and Hibbett (2003; http://www2.clarku.edu/faculty/dhibbett/Protocols_Folder/ Primers/Primers.pdf).

Samples were sequenced using the Applied Biosystems $3130 \mathrm{Ge}$ netic Analyzer (Applied Biosystems).

The sequences were aligned using ClustalW (Larkin et al., 2007) and MEGA7 (Kumar, Stecher, \& Tamura, 2016), and the consensus sequences in each region were established and deposited in DDBJ (Supplementary Table S1). Several sequences were downloaded from GenBank and UNITE (Supplementary Table S2). In the phy- logenetic analysis of each DNA region, alignment gaps were treated as missing data, and ambiguous positions were excluded from the analysis. Datasets for ITS (ITS1-5.8S-ITS2; $632 \mathrm{bp}$ ), rpb2 (472 bp), gapdh (646 bp), atp6 (373 bp), tef-1 (517 bp), mtSSU (599 bp) and IGS1 (490 bp) were prepared. Maximum likelihood (ML) and Bayesian inference analyses were conducted to clarify the phylogenetic relationships among specimens. ML trees were constructed using MEGA7 with 1000 bootstrap replicates, which followed a Tamura three-parameter for ITS and mtSSU, Kimura two-parameter for atp6, tef1, rpb2, and gapdh, or Tamura Nei model for IGS1 with a gamma distribution. For Bayesian inference analysis, the SYM model of nucleotide substitution with a discrete gamma distribution $(+\mathrm{G})$ was performed using MrBayes 3.2.1 (Ronquist et al., 2012). Two runs with four chains of Markov Chain Monte Carlo iterations were performed for 1,000,000 generations when the average standard deviation of split frequencies was below 0.01 (the first $25 \%$ of generations were treated as burn-in). Trees were kept for every 100 generations, and the remaining $75 \%$ of trees were used to calculate the $50 \%$ majority-rule consensus topology and to determine the posterior probabilities for individual branches.

\section{Results}

\section{3-1. Phylogenetic analysis of specimens based on multi-gene data}

The phylogenetic tree of the ITS region of nrDNA (Fig. 1) showed that Kakishimeji and closely related species sampled from Japan comprised five clades with strong bootstrap support values. 


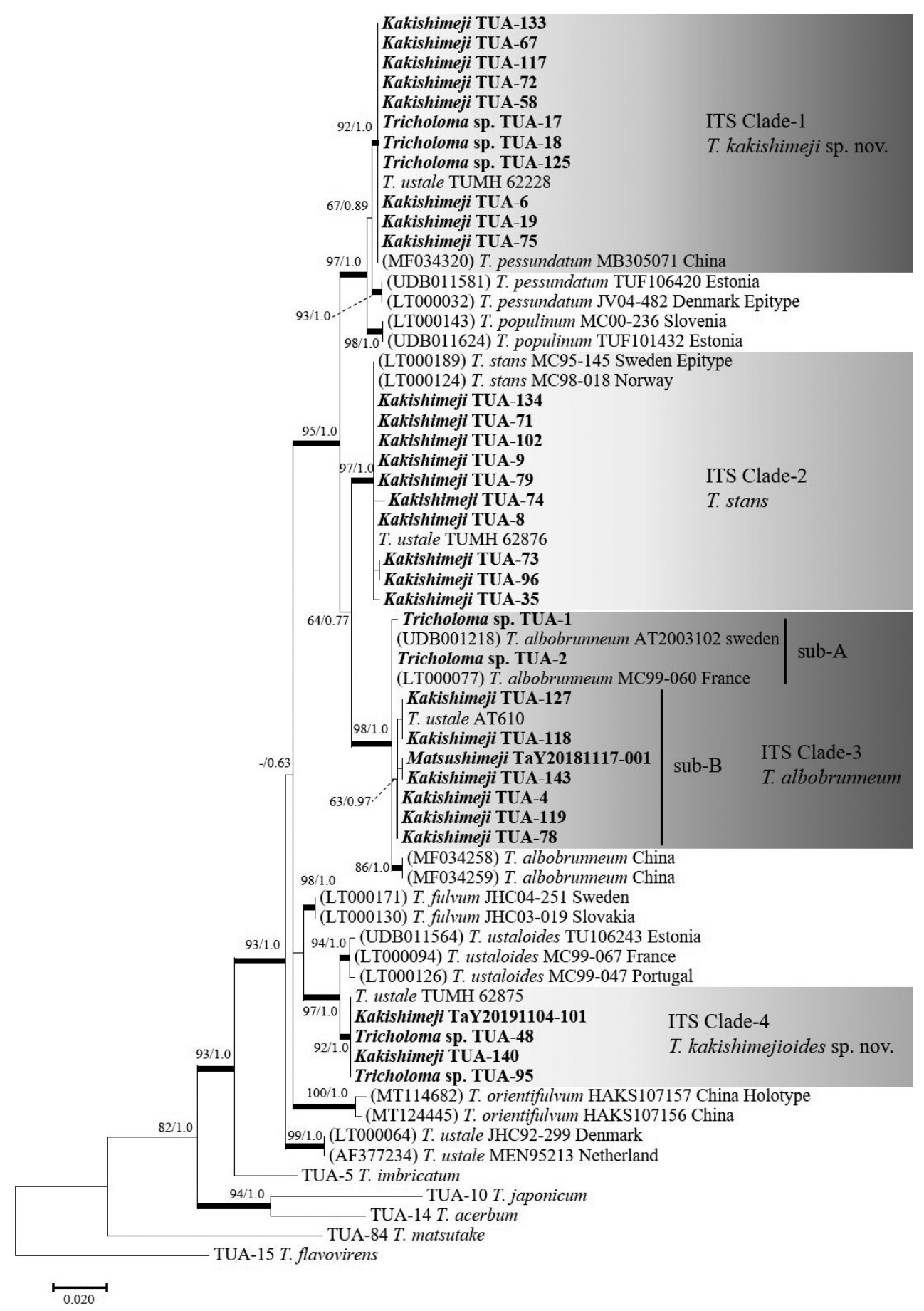

Fig. 1 - ML phylogenetic tree of the ITS1-5.8S-ITS2 region of nrDNA of Kakishimeji and closely related species. Several known Tricholoma species within and outside sect. Genuina were analyzed as outgroup species. Bootstrap (BS) values $>$ $60 \%$ from ML (left) and Bayesian posterior probabilities (PP) $>0.60$ (right) are shown near the nodes. Thick nodes indicate significant support by both BS $(>85 \%)$ and $\mathrm{PP}(>1.0)$ values. Taxon names in bold indicate the specimens examined in this study.

ITS Clade- 1 was positioned as the sister clade of European $T$. pessundatum (JV04-482; epitype specimen). Clade-2 and -3 included European specimens of T. stans (MC98-018 and MC95-145: epitype) and T. albobrunneum (MC99-060 and AT2003102), respectively. Subclade-A and -B in Clade-3 showed independent branch with moderate bootstrap probability (BP) and high posterior probability values. Clade- 4 was positioned as the sister clade to European T. ustaloides (TU106243, MC99-067, and MC99-047). Interestingly, European T. ustale clade (JHC92-299 and MEN95213) was distinct from all five phylogenetic clades of Kakishimeji and closely related species from Japan.

Phylogenetic trees of rpb2 (Fig. 2), gapdh (Supplementary Fig. S1), atp6 (Supplementary Fig. S2), tef-1 (Supplementary Fig. S3), and the IGS1 region of nrDNA (Supplementary Fig. S4) showed similar topology to that of the ITS region and comprised four distinct clades of Kakishimeji and closely related species. However, each Clade-3 corresponded to the compiled Clade-3A and -3B of the ITS phylogenetic tree. The mtSSU (Supplementary Fig. S5) 


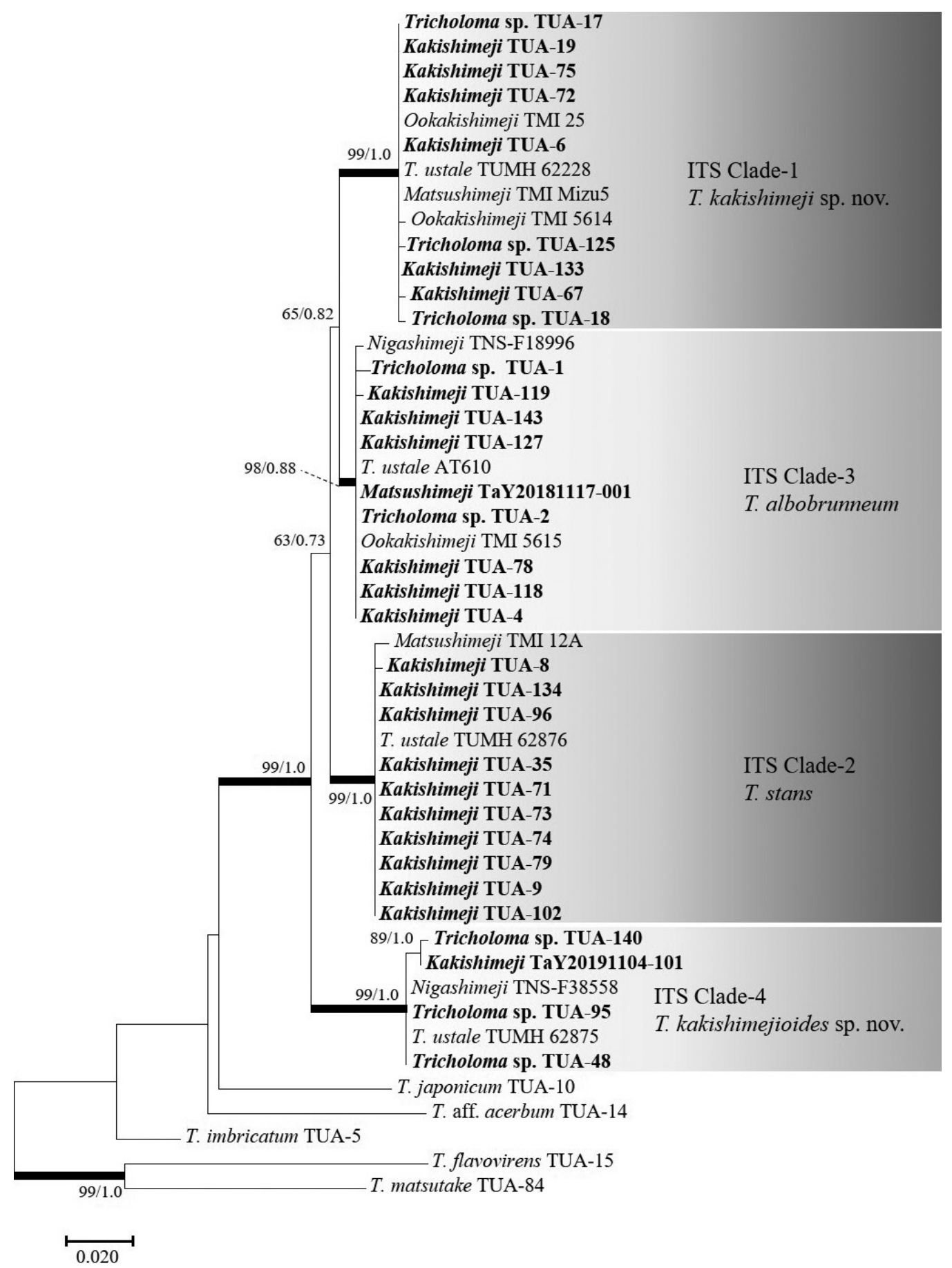

Fig. 2 - ML phylogenetic tree of rpb2 of Kakishimeji and closely related species. Several known Tricholoma species within and outside sect. Genuina were analyzed as outgroup species. Abbreviations and other indications are the same as in Fig. 1.

showed a similar topology to that of the other phylogenetic trees. However, specimens TUA-18 and TUA-75, which were in Clade-1 in the other phylogenetic trees, comprised an independent sister clade to Clade-1.

Specimens in each clade in each phylogenetic tree did not show nested relationships among phylogenetic trees, suggesting that the four clades in the ITS phylogenetic tree, i.e., Clades-1, -2, -4, and combined $-3 \mathrm{~A}$ and $-3 \mathrm{~B}$, had similar numbers of species (Supplementary Table S1). However, only specimen TUA-19 showed equivocal phylogenetic positions, i.e., Clade-1 in the ITS, rpb2, gapdh, and $\mathrm{mtSSU}$ trees and Clade- 2 in the tef1, IGS1, and atp6 trees. Sev- eral IGS1 sequences were obtained from a single basidioma specimen after cloning. However, point mutations in the sequences did not show phylogenetic diversity, and all sequences from a single specimen were within a clade (Supplementary Fig. S4).

Based on the confirmed consensus that Kakishimeji and closely related species from Japan are divided into four clades (Supplementary Table S1), we characterized the specimens in each phylogenetic clade morphologically. We regarded Clade-3A and Clade$3 \mathrm{~B}$ in the ITS phylogenetic tree as having an intraspecific relationship and treated them as Clade- 3 in the analysis. We did not use TUA-19 in the analysis due to the equivocal phylogenetic posi- 
tion, as described above.

\section{3-2. Morphological comparison of basidiomata in the phylo- genetic clades of Kakishimeji}

The pileal surface of basidiomata specimens in all four phylogenetic clades was dark reddish brown to reddish brown and viscid when moist (Figs. 3A-C, 4A, B, 5A, B, 6A). Specimens in ITS Clade-1 showed blackish spot-like scales on the pileal surface (Fig. 3C). Specimens in ITS Clade- 2 frequently showed a squamous-like fine split on top of the stipe surface (Fig. 4D). Specimens in the other clades showed this character infrequently. Specimens in ITS Clade-3 showed a striate-like structure at the pileal margin (Fig. 5C). Specimens in the other clades sometimes showed this character, albeit indistinctly. Specimens in ITS Clade-4 showed a squamous texture on the pileal surface when matured under dried conditions (Fig. 6A, B). Specimens in ITS Clades-1 and -2 had a positive (blue staining) guaiac test result (Figs. 3B, 4E), whereas those in ITS Clades-3 and -4 had a negative result (Figs. 5D, 6A).

Basidiospores were commonly ellipsoidal to subgloburous and contained a large oily droplet in fresh specimens (Figs. 3D, 4F, 5E, 6D). Spore length and width were significantly different among clades (Table 3), and the spore Q-value was significantly lower in Clade-4.

Basidia generally developed four sterigmata and contained a few oily droplets in fresh specimens (Figs. 3E, 4G, 5F, 6E). Basidia were significantly shorter in Clade- 1 than in the other three clades (Table 3). The mean basidium width differed among the clades. Sterigmata were significantly shorter in Clade-1 than in the other three clades (Table 3 ). The mean sterigma width differed among the clades (Table 3 ).

Pileipellis hyphae were cylindrical, without a clamp connection, and brown in color due to intracellular pigment (Figs. 3F, 4H, 5G, $6 \mathrm{~F})$. Subpellis consisted of ixocutis or ixotrichodermoid tissue (Figs. 3G, 4I, 5H, 6G). The mean pileipellis hyphal length was significantly shorter in Clades-1 and -2 than in Clade-3 (Table 3), while the value in Clade- 4 was intermediate. The pileipellis hyphal width was significantly greater in Clades- 1 and -3 than in Clades- 2 and -4 (Table 3 ).

Four phylogenetic clades of Kakishimeji could be distinguished morphologically (Table 4). Therefore, we assigned those clades as two new species and two new records in Japan, as below.

\section{Taxonomy}

Tricholoma kakishimeji W. Aoki \& A. Yamada, sp. nov.

Fig. 3. MycoBank no.: MB 837875.

Diagnosis: Tricholoma kakishimeji can be distinguished phylogenetically from closely resembled European $T$. pessundatum. They are also distinguishable by the pileipellis hyphal width.

Type: JAPAN, Nagano Prefecture, Shinano Town, at the foot of
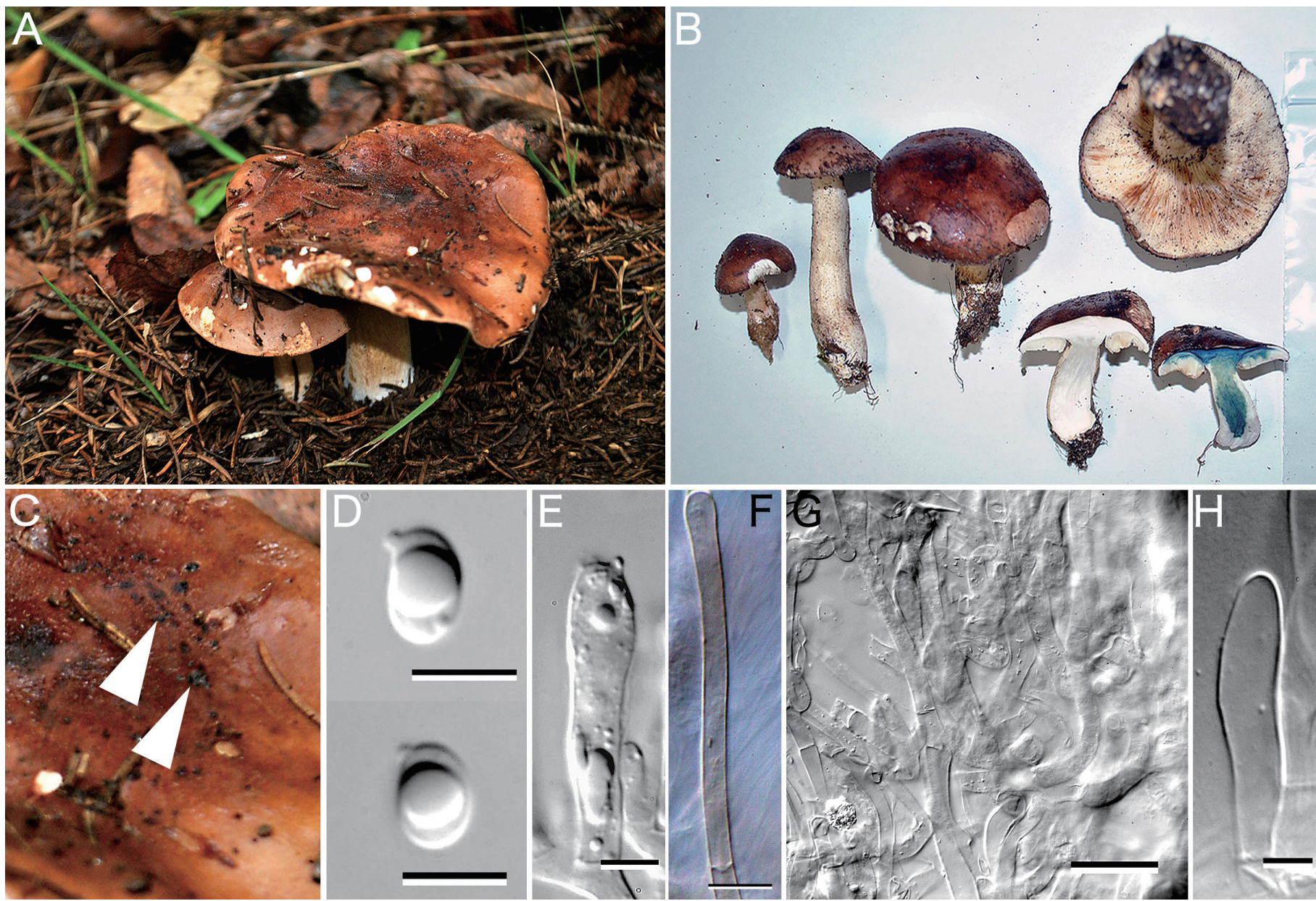

Fig. 3 - Morphological characteristics of phylogenetic ITS Clade-1 specimens (Tricholoma kakishimeji). A: External morphology of basidiomata in the field (TNS-F82064 [TUA-75]); B: external morphology of basidiomata and guaiac test (TUA-67); C: pileal surface texture showing blackish spot-like small scales (arrowhead) (TNS-F82064 [TUA75]); D: basidiospore; E: basidium; F: pileipellis hyphae; G: texture of pileipellis and subpellis; H: cystidium. Bars: D, E, H $5 \mu \mathrm{m}$; F $10 \mu \mathrm{m}$; G $20 \mu \mathrm{m}$. 

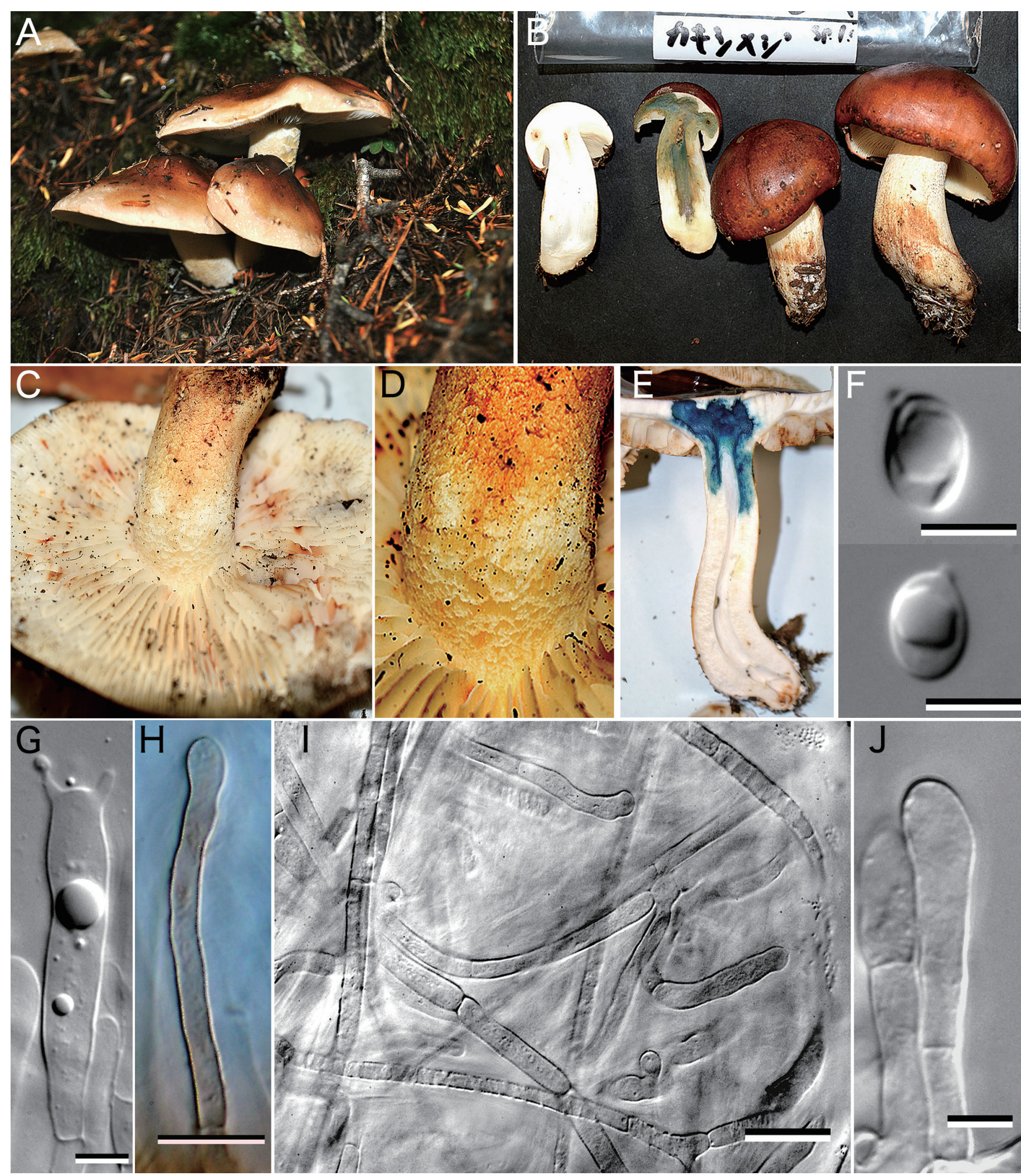

Fig. 4 - Morphological characteristics of phylogenetic ITS Clade-2 specimens (Tricholoma stans). A: External morphology of basidiomata in the field (TUA-45); B: external morphology of basidiomata and positive guaiac test (TUA-101); C: gills; D: upper part of stipe; E: positive guaiac test; F: basidiospore; G: basidium; H: pileipellis hyphae; I: pileipellis and subpellis; J: cystidium. Bars: F, G, J $5 \mu \mathrm{m} ; \mathrm{H} 10 \mu \mathrm{m} ; \mathrm{I} 20 \mu \mathrm{m}$. 

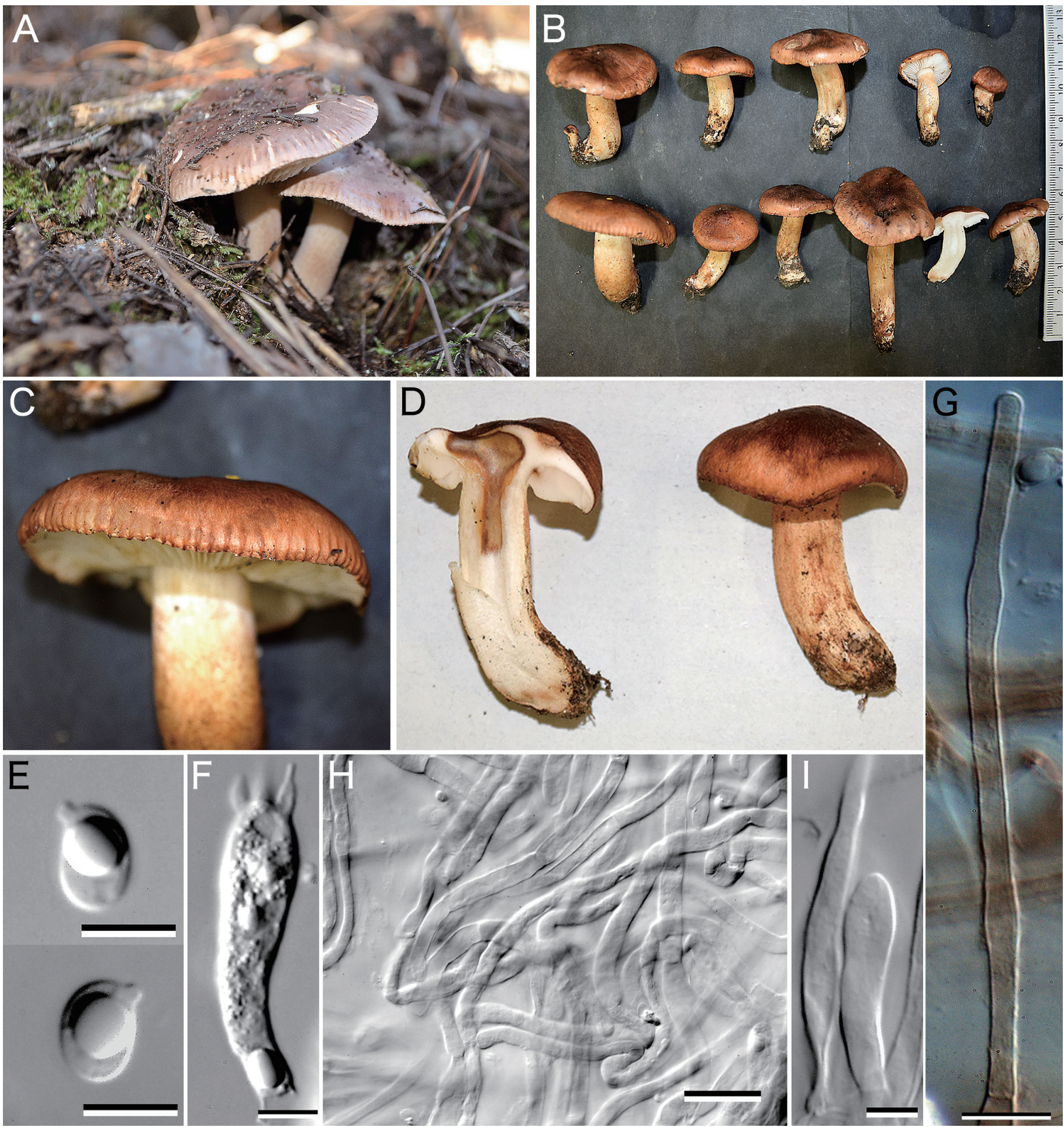

Fig. 5 - Morphological characteristics of phylogenetic ITS Clade-3 specimens (Tricholoma albobrunneum). A: External morphology of basidiomata in the field (TUA-127), B: external morphology of basidiomata (TUA-118); C: pileal margin, D: negative guaiac test; E: basidiospore; F: basidium; G: pileipellis hyphae; H: pileipellis and subpellis; I: cystidium. Bars: E, F, I $5 \mu \mathrm{m}$; G $10 \mu \mathrm{m}$; H $20 \mu \mathrm{m}$. 

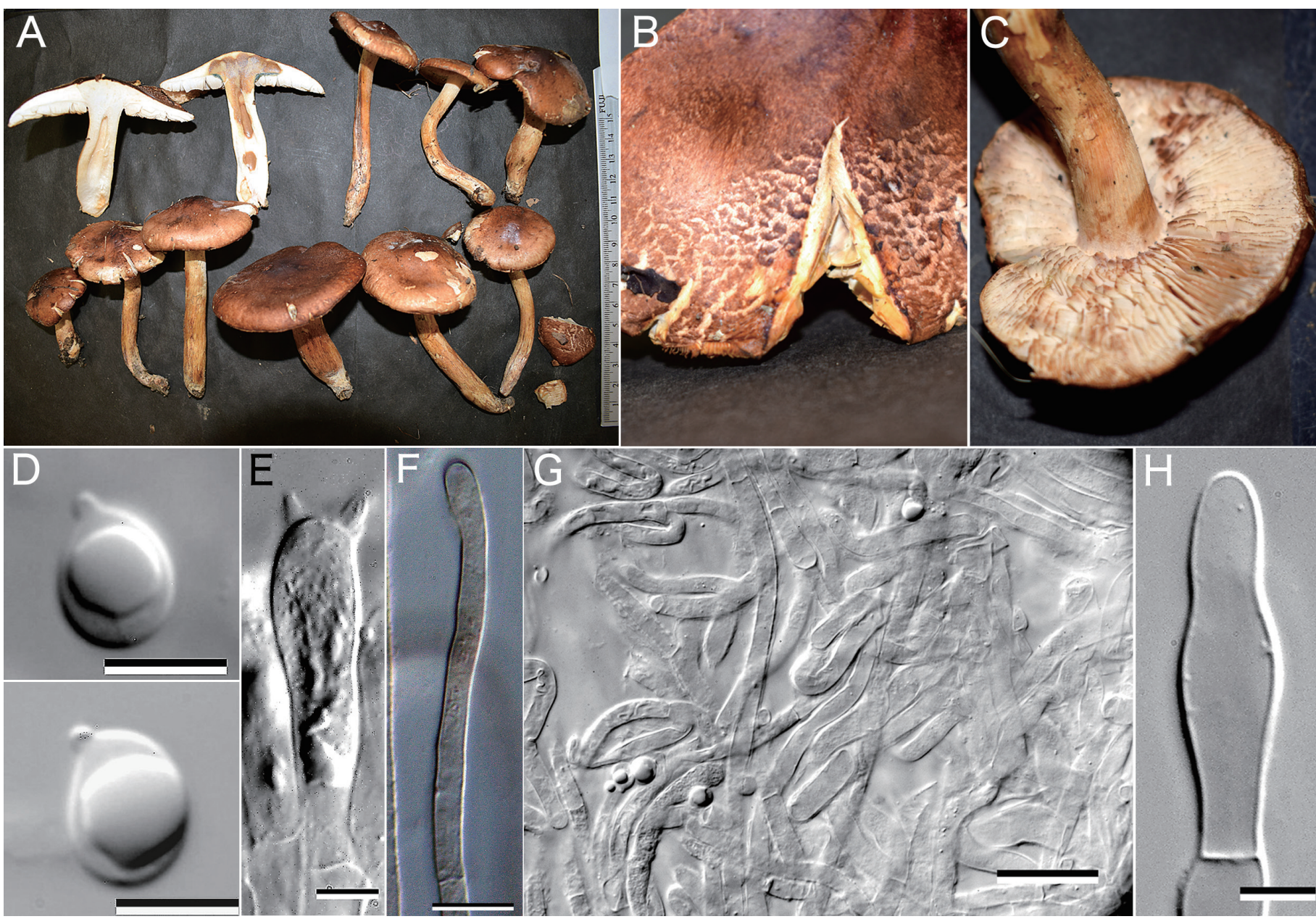

Fig. 6 - Morphological characteristics of ITS Clade-4 specimens (Tricholoma kakishimejioides). A: External morphology of basidiomata (TNS-F82065 [TaY20191104-101]) and a weakly positive guaiac test; B: pileal margin texture; C: gills; D: basidiospore; E: basidium; F: pileipellis hyphae; G: pileipellis and subpellis; H: cystidium. Bars: D, E, H 5 um; F $10 \mu \mathrm{m} ; \mathrm{G} 20 \mu \mathrm{m}$.

Table 3 Microscopic comparison of four Tricholoma species in "Kakishimeji" complex distinguished by the phylogenetic analyses.

\begin{tabular}{|c|c|c|c|c|c|c|c|c|c|c|c|c|c|}
\hline \multirow{2}{*}{\multicolumn{2}{|c|}{$\begin{array}{c}\text { Measured } \\
\text { parameters }\end{array}$}} & \multicolumn{3}{|c|}{$\begin{array}{c}\text { Clade-1 } \\
\text { T. kakishimeji }\end{array}$} & \multicolumn{3}{|c|}{$\begin{array}{l}\text { Clade- } 2 \\
\text { T. stans }\end{array}$} & \multicolumn{3}{|c|}{$\begin{array}{c}\text { Clade-3 } \\
\text { T. albobrunneum }\end{array}$} & \multicolumn{3}{|c|}{$\begin{array}{c}\text { Clade-4 } \\
\text { T. kakishimejioides }\end{array}$} \\
\hline & & $\mathrm{N}^{2}$ & Min-Ave--Max ${ }^{3}$ & $S^{4}$ & $\mathrm{~N}$ & Min-Ave-Max & $\mathrm{S}$ & $\mathrm{N}$ & Min-Ave-Max & $\mathrm{S}$ & $\mathrm{N}$ & Min-Ave-Max & $\mathrm{S}$ \\
\hline \multirow{3}{*}{$\begin{array}{l}\text { Basidio- } \\
\text { spore }\end{array}$} & $\mathrm{L}^{1}$ & \multirow{3}{*}{14} & $4.1-4.6-5.0$ & $\mathrm{C}$ & \multirow{3}{*}{27} & $4.9-5.5-6.2$ & A & \multirow{3}{*}{14} & $4.5-4.9-5.7$ & B & \multirow{3}{*}{4} & $5.4-5.8-6.6$ & A \\
\hline & $\mathrm{W}^{1}$ & & $3.0-3.3-3.9$ & $\mathrm{C}$ & & $3.5-3.9-4.3$ & B & & $3.1-3.5-3.9$ & $\mathrm{C}$ & & $4.2-4.5-5.1$ & A \\
\hline & $\mathrm{Q}^{1}$ & & $1.3-1.4-1.6$ & A & & $1.3-1.4-1.5$ & A & & $1.3-1.4-1.5$ & A & & $1.2-1.3-1.4$ & B \\
\hline \multirow{2}{*}{ Basidium } & $\mathrm{L}$ & \multirow{2}{*}{12} & $20.6-23.9-27.0$ & $\mathrm{C}$ & \multirow{2}{*}{21} & $23.3-27.9-31.5$ & A & \multirow{2}{*}{13} & $23.1-26.0-27.9$ & B & \multirow{2}{*}{3} & $25.6-27.5-29.1$ & A \\
\hline & W & & $4.7-5.2-6.2$ & $\mathrm{C}$ & & $3.9-5.9-6.8$ & $\mathrm{AB}$ & & $4.9-5.5-6.3$ & B & & $6.1-6.8-8.0$ & A \\
\hline \multirow{2}{*}{ Sterigma } & $\mathrm{L}$ & \multirow{2}{*}{12} & $1.4-2.0-3.1$ & B & \multirow{2}{*}{21} & $1.5-3.0-4.2$ & A & \multirow{2}{*}{12} & $2.4-3.1-3.8$ & A & \multirow{2}{*}{3} & $3.3-3.6-3.8$ & A \\
\hline & $\mathrm{W}$ & & $1.0-1.3-1.5$ & $\mathrm{AB}$ & & $0.9-1.2-1.5$ & B & & $0.9-1.3-1.5$ & $\mathrm{AB}$ & & $1.2-1.6-2.3$ & A \\
\hline \multirow{2}{*}{ Pileipellis } & $\mathrm{L}$ & \multirow{2}{*}{8} & $41.6-50.6-56.2$ & B & \multirow{2}{*}{13} & $41.8-52.6-68.9$ & B & \multirow{2}{*}{10} & $49.4-61.3-72.9$ & A & \multirow{2}{*}{3} & $54.4-56.3-58.0$ & $\mathrm{AB}$ \\
\hline & W & & $4.0-5.1-7.0$ & A & & $3.2-3.9-4.9$ & B & & $4.6-5.2-5.8$ & A & & $3.7-3.9-4.2$ & $\mathrm{~B}$ \\
\hline
\end{tabular}

${ }^{1}$ L: Length $(\mu \mathrm{m})$, W: Width $(\mu \mathrm{m})$, Q: Q-value (length/width).

${ }^{2} \mathrm{~N}$ : number of specimens measured for the size.

${ }^{3}$ The indicated numerical data are based on mean values in each specimen, which were used for the statistical analysis.

${ }^{4} \mathrm{~S}$ : Different alphabets indicate significant difference of means between species at $P<0.05$. 
Table 4 Morphological comparison between T. kakishimeji and related species

$\begin{array}{llll}\text { ITS Clade-1 } & \text { ITS Clade-2 } & \text { ITS Clade-3 } & \text { ITS Clade-4 } \\ \text { T. kakishimeji } & \text { T. stans } & \text { T. albobrunneum } & \text { T. kakishimejioides }\end{array}$

\begin{tabular}{|c|c|c|c|c|c|}
\hline $\begin{array}{l}\text { Shape and } \\
\text { surface } \\
\text { texture of } \\
\text { pileus }\end{array}$ & $\begin{array}{l}\text { First convex and later flat, of- } \\
\text { ten with dark brown to black- } \\
\text { ish spot-like small scales }\end{array}$ & $\begin{array}{l}\text { First semispherical to convex, } \\
\text { later low convex or flat, rarely } \\
\text { with dark brown to blackish } \\
\text { spot-like small scales }\end{array}$ & $\begin{array}{l}\text { First convex, later flat, margin } \\
\text { striate, viscid when moist }\end{array}$ & $\begin{array}{l}\text { First convex, later flat, squa- } \\
\text { mous-like under dry weather } \\
\text { condition }\end{array}$ & $\begin{array}{l}\text { First hemisphere to bell-shaped, } \\
\text { later convex to flattened with } \\
\text { low }\end{array}$ \\
\hline $\begin{array}{l}\text { Pileus } \\
\text { color }\end{array}$ & $\begin{array}{l}\text { Center dark brown to brown, } \\
\text { reddish brown or pale brown } \\
\text { in the margin }\end{array}$ & $\begin{array}{l}\text { Center dark reddish brown, } \\
\text { reddish brown pale to margin }\end{array}$ & $\begin{array}{l}\text { Reddish brown, dark brown } \\
\text { in center, and paler color in } \\
\text { the margin }\end{array}$ & $\begin{array}{l}\text { Center dark reddish brown to } \\
\text { reddish brown, reddish brown } \\
\text { to pale brown in the margin }\end{array}$ & $\begin{array}{l}\text { Central part yellowish brown, } \\
\text { dark brick to fuscous or um- } \\
\text { ber, towards margin paler }\end{array}$ \\
\hline $\begin{array}{l}\text { Shape of } \\
\text { gills }\end{array}$ & Crowded & Crowded & Close & Close & Medium space to crowded \\
\hline $\begin{array}{l}\text { Color and } \\
\text { shape of } \\
\text { stipe }\end{array}$ & White to brown, hollow & $\begin{array}{l}\text { White, later pale brown, top } \\
\text { surface is distinctly squamous }\end{array}$ & $\begin{array}{l}\text { White or brownish, powdery } \\
\text { at the top surface }\end{array}$ & Pale brown to brown & Whitish to pale chrome at top \\
\hline Spore size & $\begin{array}{l}4.1-4.6-5.0 \times 3.0-3.3-3.9 \mu \mathrm{m} \\
Q=1.3-1.4-1.6\end{array}$ & $\begin{array}{l}4.9-5.5-6.2 \times 3.5-3.9-4.3 \mu \mathrm{m} \\
Q=1.3-1.4-1.5\end{array}$ & $\begin{array}{l}4.5-4.9-5.7 \times 3.1-3.5-3.9 \mu \mathrm{m} \\
Q=1.3-1.4-1.5\end{array}$ & $\begin{array}{l}5.4-5.8-6.6 \times 4.2-4.5-5.1 \mu \mathrm{m} \\
Q=1.2-1.3-1.4\end{array}$ & $\begin{array}{l}6.1-6.9 \times 5.1-5.7 \mu \mathrm{m}, \mathrm{Q}=1.18- \\
1.32\end{array}$ \\
\hline Basidium & $20.6-23.9-27.0 \times 4.7-5.2-6.2 \mu \mathrm{m}$ & $23.3-27.9-31.5 \times 3.9-5.9-6.8 \mu \mathrm{m}$ & $23.1-26.0-27.9 \times 4.9-5.5-6.3 \mu \mathrm{m}$ & $25.6-27.5-29.1 \times 6.1-6.8-8.0 \mu \mathrm{m}$ & $35-50 \times 7.0-9.0 \mu \mathrm{m}$ \\
\hline Sterigma & $1.4-2.0-3.1 \times 1.0-1.3-1.5 \mu \mathrm{m}$ & $1.5-3.0-4.2 \times 0.9-1.2-1.5 \mu \mathrm{m}$ & $2.4-3.1-3.8 \times 0.9-1.3-1.5 \mu \mathrm{m}$ & $3.3-3.6-3.8 \times 1.2-1.6-2.3 \mu \mathrm{m}$ & - \\
\hline Pileipellis & $41.6-50.6-56.2 \times 4.0-5.1-7.0 \mu \mathrm{m}$ & $41.8-52.6-68.9 \times 3.2-3.9-4.9 \mu \mathrm{m}$ & $49.4-61.3-72.9 \times 4.6-5.2-5.8 \mu \mathrm{m}$ & $54.4-56.3-58.0 \times 3.7-3.9-4.2 \mu \mathrm{m}$ & $2.5-5.0 \mu \mathrm{m}$ \\
\hline $\begin{array}{l}\text { Canopy } \\
\text { vegetation }\end{array}$ & Fagaceae, Pinaceae & Fagaceae, Pinacese & Pinus & Fagaceae & Fagus \\
\hline $\begin{array}{l}\text { Climate of } \\
\text { habitat }\end{array}$ & Temperate & Temperate to subalpine & Temperate to alpine & Temperate & Temperate \\
\hline
\end{tabular}

Mt. Iizuna-yama, $36^{\circ} 44^{\prime} 48.20^{\prime \prime} \mathrm{N}, 138^{\circ} 11^{\prime} 24.32^{\prime \prime} \mathrm{E}$, alt $842 \mathrm{~m}$, in a small man-made stand of Picea abies surrounded by a mixed forest of Quercus serrata, Q. crispula, and Pinus densiflora, 17 Oct 2018, leg. W. Aoki (holotype, TNS-F82064 [TUA-75]).

Gene sequences ex-holotype: LC589085 (nrDNA ITS; Clade-1 in Fig. 1), LC587217 (nrDNA IGS), LC587129 (tef-1), LC586915 (gapdh), LC586873 (rpb2), LC587164 (mtSSU), LC587087 (atp6).

Etymology: Kakishimeji, common name of this fungus in Japan.

Description: Pileus 6-8 cm diam, center dark brown to brown, reddish brown or pale brown in the margin (Fig. 3A, B), first convex and lately flat, margin involved and lately flat, surface innately fibrillose and viscid when moist, often with a few or many dark brown to blackish spot-like small scales (Fig. 3C). Stipe white to brown, hollow, cylindrical or tapering upwards. Gills white, cloudy, sinuate, lately with frequent brown stains. Flesh white, guaiac test positive (Fig. 3B), smell moderate to strong farinaceous, taste bitter in the pileal surface, faintly bitter or mild in the inner tissue. Basidiospores 4.1-4.6-5.0 × 3.0-3.3-3.9 $\mu \mathrm{m}$ (minimum-average-maximum values of length $\times$ minimum-average-maximum values of width), Q (length/width) = 1.3-1.4-1.6, ellipsoidal, non-amyloid, single intracellular large transparent oily droplet in fresh materials (Fig. 3D). Basidia 20.6-23.9-27.0 × 4.7-5.2-6.2 $\mu \mathrm{m}$, clavate to subcylindrical, four-spored, several intracellular transparent oily droplets in fresh materials, clamp connections not observed on the basal septum (Fig. 3E). Sterigmata 1.4-2.0-3.1 $\times$ 1.0-1.3-1.5 $\mu \mathrm{m}$ (Fig. 3E). Pileipellis ixocutis, hyphae 41.6-50.6$56.2 \times 4.0-5.1-7.0 \mu \mathrm{m}$, cylindrical, intracellular brown pigment (Fig. 3F, G), no clamp connections. Stipitipellis 19.5-38.7-63.6 $\times$ 3.6-5.8-8.8 $\mu \mathrm{m}$, colorless to pale brown, smooth, cylindrical, no clamp connections, occasionally cystidia-like structures were observed on top surface of the top of stipe, clavate to cylindrical, colorless, no clamp connections (Fig. 3H).

Specimens examined other than holotype: JAPAN: Aomori Prefecture: TUA-18 (A. Yamada); Nagano Prefecture: TUA-6 (A. Yama$d a$ ), TUA-17 (N. Endo), TUA-19 (A. Yamada), TUA-58 (W. Aoki), TUA-67 (W. Aoki), TUA-75 (W. Aoki), TUA-117 (W. Aoki), TUA-125 (A. Yamada); Tottori Prefecture: TUA-133 (W. Aoki), TUMH 62228 (N. Endo); Hokkaido: TMI 5614 (S. Imai); Yamanashi Prefecture: TMI Mizu5 (S. Imai).

GenBank accession number of DNA sequences: see Supplemen- tary Table S1 (nrDNA ITS Clade-1).

Ecology: Tricholoma kakishimeji is distributed under temperate zone, in Fagaceae and Pinaceae forests, fruiting during Oct-Nov.

Comments: Tricholoma kakishimeji is microscopically similar to Japanese T. ustale reported by Kawamura (1929) and T. albobrunneum reported by Imai (1938), but basidium size is smaller in $T$. kakishimeji than T. albobrunneum sensu Imai. Macroscopically, pileal surface of T. kakishimeji has few to many small dark-brown spot-like scales, similar to T. pessundatum (Fr.: Fr.) Quélet (Christensen \& Heilmann-Clausen, 2013). However, as this character was sometimes observed even in Japanese T. stans specimens, it cannot be used to distinguish T. kakishimeji and T. stans. Pileipellis hyphal width of T. pessundatum is $2.0-4.5 \mu \mathrm{m}$, thinner than that of T. kakishimeji. The ecology of T. kakishimeji and T. pessundatum is largely overlapped, i.e., Fagaceous tree associations. T. kakishimeji prominently contains a toxic compound, ustalic acid, but the other closely resembled Japanese Tricholoma species distinguished in this study harbor this compound at negligible levels (Ito et al., 2021). The T. pessundatum TMI 5614 specimen sampled in Hokkaido in 1933 and used for the description of this species as new to Japan under the common name "Ookakishimeji" (Imai, 1938) was synonymized with T. kakishimeji based on its phylogenetic position (Fig. 2) and morphological characteristics.

Tricholoma kakishimejioides W. Aoki \& A. Yamada, sp. nov. Fig. 6. MycoBank no.: MB 837876.

Diagnosis: Tricholoma kakishimejioides can be distinguished phylogenetically from closely related European T. ustaloides. They are distinguishable by the pileipellis hyphal width.

Type: JAPAN, Nara Prefecture, Kashihara City, Kashihara-jingu Shrine, $34^{\circ} 29^{\prime} 11^{\prime \prime} \mathrm{N}, 135^{\circ} 47^{\prime} 26^{\prime \prime} \mathrm{E}$, alt $72 \mathrm{~m}$, in a broad-leaved forest dominated by Castanopsis sieboldii and Quercus glauca with sporadic Abies firma, 4 Nov 2019, leg. N. Endo (holotype, TNS-F82065 [TaY20191104-101]).

Gene sequences ex-holotype: LC574895 (nrDNA ITS; Clade-4 in Fig. 1), LC587186 (nrDNA IGS), LC587109 (tef-1), LC586899 (gapdh), LC586850 (rpb2), LC587180 (mtSSU), LC587069 (atp6).

Etymology: Look-alike species to Tricholoma kakishimeji.

Description: Pileus 3-6 cm diam, center dark reddish brown to 
reddish brown, reddish brown to pale brown in the margin, firstly convex, later flat, margin involved, surface innately fibrillose, squamous-like in dry weather (Fig. 6A, B), viscid when moist. Stipe pale brown to brown, hollow, cylindrical or tapered slightly toward the base. Gills white, close, sinuate, lately with frequent brown stains (Fig. 6C). Flesh white, thick, guaiac test largely negative but faintly positive (Fig. 6A), smell strongly farinaceous, taste bitter in the pileal surface, faintly bitter or mild in the inner tissue. Basidiospores 5.4-5.8-6.6 × 4.2-4.5-5.1 $\mu \mathrm{m}, \mathrm{Q}=1.2-1.3-1.4$, subglabrous to glabrous, non-amyloid, single intracellular large transparent oily droplet in fresh material (Fig. 6D). Basidia 25.6-27.5-29.1 × 6.16.8-7.9 $\mu \mathrm{m}$, clavate to cylindrical, four-spored, several intracellular large transparent oily droplets in fresh material (Fig. 6E), non-amyloid, clamp connections not observed on the basal septum. Sterigmata 3.3-3.6-3.8 × 1.2-1.6-2.3 $\mu \mathrm{m}$ (Fig. 6E). Pileipellis ixocutis to ixotrichoderm, smooth, hyphae 54.4-56.3-58.0 × 3.7-3.9-4.2 $\mu \mathrm{m}$, cylindrical, intracellular brown pigment (Fig. 6F, G). Stipitipellis 30.3-51.1-85.7 × 2.3-3.9-6.2 $\mu \mathrm{m}$, colorless to pale brown, smooth, cylindrical, no clamp connections, occasionally cystidium-like structures are observed on the surface of the top of stipe, clavate to cylindrical, colorless, no clamp connections (Fig. 6H).

Specimens examined other than holotype: JAPAN: Nagano Prefecture: TUA-48 (W. Aoki), TUA-95 (W. Aoki); Tottori Prefecture: TUA-140 (W. Aoki), TUMH 62875 (N. Endo); Nara Prefecture: TaY20191104-101 (N. Endo); Ishikawa Prefecture: TNS-F38558 (Y. Ikeda).

GenBank accession numbers of DNA sequences: see Supplementary Table S1 (nrDNA ITS Clade-4).

Ecology: Tricholoma kakishimejioides is distributed in Fagaceae forests in warm temperate zones, fruiting during Sep-Nov.

Comments: Tricholoma kakishimejioides can be distinguish from T. stans, T. albobrunneum, and T. kakishimeji by the spore shape. T. ustaloides Romagn., sister clade to T. kakishimejioides (Fig. 1), has a larger basidium, i.e., 30-50 $\mu \mathrm{m}$ in length according to Christensen and Heilmann-Clausen (2013) or 29.5-37.5 $\mu \mathrm{m}$ according to Halama et al. (2016). Although several reports of T. ustaloides are known from Japan with the common name of $\mathrm{Ni}$ gashimeji, most of those descriptions are confused with closely related species. In fact, T. ustaloides TNS-F18996 used for the description of Nigashimeji (Ikeda, 2005) was identified as T. albobrunneum (Fig. 2). Therefore, we rejected the description of $\mathrm{Ni}$ gashimeji. The ecology of T. kakishimejioides and T. ustaloides is shared, i.e., Quercus associations, which was first emphasized in the report of Kakishimeji-modoki (look-alike species to Kakishime$j i$ ) by Miyauchi (1989). Therefore, we adopted the common name to the epithet.

Tricholoma stans (Fr.) Sacc. Sylloge fungorum, Sylloge Hymenomycetum, Vol. 1. Agaricineae, 5: 94, 1887. Fig. 4.

= Tricholoma maculatipus Hongo \& Matsuda, Journal of Japanese Botany, 37: 369, 1962.

= Tricholoma maculatipes Hongo \& Matsuda, Memoirs of the Faculty of Education, Shiga University, Natural Science, 33: $38,1983$.

Description: Pileus 6-13 cm diam, first semispherical to convex, later low convex or flat (Fig. 4A, B), center dark reddish brown, reddish brown pale to margin, surface innately fibrillose or unclearly fibrillose, viscous when moist, rarely with dark brown to small blackish spot-like scales. Stipe white, later pale brown, cylindrical to robust, hollow to medulla, top surface is distinctly squamous (Fig. 4C, D). Gills white, cloudy, thick, sinuate, later brown stained (Fig. 4C). Flesh white, guaiac test is positive (Fig. 4B, E), slightly bitter in the pileal surface, mild in other parts, smell farinaceous. Basidiospores 4.9-5.5-6.2 × 3.5-3.9-4.3 $\mu \mathrm{m}, \mathrm{Q}=1.3-1.4-$ 1.5, ellipsoidal to predominantly ellipsoidal, single intracellular achromatic oily droplet in fresh material (Fig. 4F), non-amyloid. Basidia 23.3-27.9-31.5 × 3.9-5.9-6.8 $\mu \mathrm{m}$, clavate to cylindrical, four-spored, several intracellular achromatic oily droplets in fresh material (Fig. 4G), non-amyloid, clamp connections not observed on the basal septum of a basidium. Sterigmata 1.5-3.0-4.2 $\times 0.9-$ 1.2-1.5 $\mu \mathrm{m}$ (Fig. 4G). Pileipellis ixocutis to ixotrichoderm, hyphae 41.8-52.6-68.9 × 3.2-3.9-4.9 $\mu \mathrm{m}$, cylindrical, straight, intracellular brown pigment, no clamp connections (Fig. 4H, I). Stipitipellis cuitis, hyphae $22.8-46.1-91.7 \times 2.9-4.6-7.6 \mu \mathrm{m}$, colorless to palebrown, smooth, cylindrical, no clamp connections, occasionally cystidium-like structures were observed on the surface of the top of stipe, clavate to cylindrical, colorless, no clamp connections (Fig. 4J).

Specimens examined: JAPAN, Nagano Prefecture: TUA-9 $(A$. Yamada), TUA-102 (W. Aoki), TUA-8 (W. Aoki), TUA-73 (W. Aoki), TUA-96 (A. Yamada), TUA-35 (W. Aoki), TUA-74 (W. Aoki); Shizuoka Prefecture: TUA-79 (A. Yamada); Tottori Prefecture: TUMH 62876 (N. Endo), TUA-134 (W. Aoki); Yamanashi Prefecture: TMI 12A (S. Imai); Yamagata Prefecture: OMNH 2392 (T. Hongo); OMNH 3162 (T. Hongo).

GenBank accession numbers of DNA sequences: see Supplementary Table S1 (nrDNA ITS Clade-2).

Ecology: Japanese Tricholoma stans is distributed in warm temperate to subalpine zones on Honshu and Hokkaido Islands under various Fagaceae and Pinaceae trees, especially under Abies veitchii and Tsuga diversifolia in subalpine zone on Honshu Island, fruiting Sep-Nov.

Japanese common name: “Azashimeji” named by Matsuda and Hongo (1962).

Comment: Tricholoma stans has relatively large spores compared with T. kakishimeji and T. albobrunneum (see below) and larger Q-value compared with T. kakishimejioides (see above). In addition, pileipellis hyphae of $T$. stans are thinner than those of $T$. kakishimeji and T. albobrunneum. These T. stans characteristics suggest similarity to Ookakishimeji identified as T. pessundatum (Fr.) Quél. by Imai (1938) and Ito (1959). However, no T. pessundatum specimens identified by S. Imai matched the T. stans clade (Clade-2) in the phylogenetic analysis (Fig. 2). Although T. stans was once reported from Niigata Prefecture, Japan with the common name Matsubarashimeji (Miyauchi, 2010), this fungus has a distinctly squamous pileal surface, suggesting membership in the T. imbricatum group. We conducted DNA analysis of atp6 in two Azashimeji specimens, OMNH 2392 and OMNH 3162, and found that they belonged to T. stans (Clade-2) (Supplementary Fig. S2). However, Azashimeji and T. stans descriptions showed slight morphological differences, i.e., pileal center is squamulose ("centro minute squamuloso") in Azashimeji (Matsuda \& Hongo, 1962). As a new species, the name T. maculatipus was used for Azashimeji (Matsuda \& Hongo, 1962). Subsequently, Hongo (1983) reported this species as being new to Shiga Prefecture, but misspelled the fungus as " $T$. maculatipes". Recently, Katsumoto compiled references for this fungus, but unfortunately also used the wrong spelling, T. maculatipes. We checked the spelling on the labels of the specimens used by Matsuda \& Hongo (1962) and Hongo (1983) and all were labelled T. maculatipus. Therefore, we consider T. maculatipus as the correct spelling and reject T. maculatipes.

All gene regions tested, except for atp6 in Azashimeji specimens, failed sequencing due to degradation of basidioma tissue. Based on the accumulated data for Azashimeji, i.e., phylogenetic, morphological, and ecological characteristics, we synonymized T. macu- 
latipus to T. stans. The geographic distribution of T. stans in Europe is limited to boreal Fennoscandia and Denmark (Christensen \& Heilmann-Clausen, 2013), but Japanese T. stans is distributed from subalpine to warm temperate zones in Quercus and Fagus forests. Therefore, Japanese $T$. stans populations include greater genetic variation compared with European populations.

Tricholoma albobrunneum (Pers.) P. Kumm., Der Führer in die Pilzkunde; 129, 1871. Fig. 5.

Description: Pileus firstly convex and later flat, margin involved and flat when matured, reddish brown, dark brown in center, and paler color in the margin, surface innately fibrillose, margin fibrillose and striate, viscid when moist (Fig. 5A-C). Stipe white or brownish, cylindrical to tapering slightly toward the base, hollow or medulla, powdery at the top surface (Fig. 5C). Gills white, close, later brownish stains occurred (Fig. 5B-D). Flesh white, thick, guaiac test negative (Fig. 5D), smell farinaceous, taste slightly bitter in pileal surface. Basidiospores 4.5-4.9-5.7 × 3.1-3.5-3.9 $\mu \mathrm{m}, \mathrm{Q}=$ 1.3-1.4-1.5, ellipsoidal to predominantly ellipsoidal, single intracellular large achromatic oily droplet in fresh material (Fig. 5E). Basidia 23.1-26.0-27.9 × 4.9-5.5-6.3 $\mu \mathrm{m}$, clavate to near cylindrical, four-spored, several intracellular transparent oily droplets when fresh materials were observed, non-amyloid, clamp connections not observed on the basal septum of a basidium (Fig. 5F). Sterigmata 2.4-3.1-3.8 $\times$ 0.9-1.3-1.5 $\mu \mathrm{m}$ (Fig. 5F). Pileipellis ixocutis to ixotrichoderm, hyphae, 49.4-61.3-72.9 $\times$ 4.6-5.2-5.8 $\mu \mathrm{m}$, cylindrical, intracellular brown pigment, no clamp connections (Fig. 5G, H). Stipitipellis 31.3-53.6-82.5 × 5.0-6.7-9.6 $\mu \mathrm{m}$ (TUA-127), cuitis, hyaline to pale brown, smooth, cylindrical, no clamp connections, occasionally cystidium-like structures were observed on the surface of top of stem, clavate to cylindrical, colorless, no clamp connections (Fig. 5I).

Specimens examined: JAPAN: Hokkaido: TUA-1 (A. Yamada), TUA-2 (A. Yamada), TMI 5615 (S. Imai); Nagano Prefecture: TUA-4 (A. Yamada), TUA-78 (W. Aoki), TUA-118 (W. Aoki), TUA-119 (W. Aoki), OMNH 2802 (T. Hongo); Tottori Prefecture: TUA-127 (W. Aoki), TUA-143 (W. Aoki), TaY20181117-001 (N. Endo); Ishikawa Prefecture: TNS-F18996 (Y. Ikeda); Ibaraki Prefecture: TMI Fukuroda 52 (S. Imai); Shiga Prefecture: OMNH 1756 (T. Hongo), OMNH 1938 (T. Hongo), OMNH 1947 (T. Hongo), OMNH 3008 (T. Hongo), OMNH 3606 (T. Hongo).

GenBank accession number of DNA sequences: see Supplementary Table S1 (nrDNA ITS Clade-3A, -3B).

Ecology: Japanese Tricholoma albobrunneum is specifically found in two-needle pine stands, i.e., Pinus densiflora and P. thunbergii, established in coastal and inland mountain regions in the temperate zone on Honshu Island; and in five-needle pine shrubs, i.e., $P$. pumila, established in mountain regions in the alpine zone on Mt. Rishiri-dake, Hokkaido. Other five-needle pines, e.g., $P$. parviflora and $P$. koraiensis, are also potential hosts. Fruiting in Sep-Dec, rarely in Jun.

Japanese common name: Matsushimeji adopted by S. Imai (1938) from the old name of this mushroom.

Comment: Japanese T. albobrunneum showed a smaller trend in basidium size compared with European T. albobrunneum, which was regarded as intraspecific variation in the present study, because other morphological characteristics and phylogenetic data support the conspecificity. Pileipellis hyphae of Japanese T. albobrunneum tended to be longer compared with those of T. stans, $T$. kakishimeji, and T. kakishimejioides. The striate character on the pileal margin is unique to T. albobrunneum compared with these other three species, despite the variation in each specimen of this species and T. stans. This species has been confused with these three species since Imazeki (1942). Descriptions of Japanese T. albobrunneum by Imazeki (1942) and Imazeki and Hongo (1957) were regarded to be $T$. kakishimeji in the present study based on their macroscopic features and spore size. In contrast, T. ustale sensu Imazeki and Hongo $(1965,1987)$ were regarded to be T. albobrunneum in the present study. In addition, the T. pessundatum TMI 5615 specimen used for the species description as new to Japan as well as TMI 5614 under the common name Ookakishimeji (Imai, 1938) was identified as T. albobrunneum based on the rpb2 phylogeny (Fig. 2). Two T. albobrunneum specimens identified by S. Imai (TMI Mizu5 and TMI 12A) were unfortunately included in the T. kakishimeji and T. stans clades, respectively, in the rpb2 phylogeny (Fig. 2). At present, no T. albobrunneum specimens identified by S. Imai as the species are available to confirm the validity of the phylogenetic analyses. However, because the T. albobrunneum TMI Fukuroda 52 specimen sampled in Ibaraki Prefecture and used for the species description as new to Japan (Imai, 1938) was confirmed to have the species microscopic features, we adopted the common name Matsushimeji (i.e., pine-associated shimeji mushroom in Japanese) for T. albobrunneum. In addition, the habitat properties of $T$. albobrunneum basidioma, including "especially under Pinus", reported by Imai (1938) support the validity of his identification. A survey of older scientific records of T. albobrunne$u m$ in Japan dating back to 1917 showed that K. Minakata recorded a drawing of "Matsushimeji" as T. cryptica (Hagiwara, 2007), based on the striate at the pileal margin and other external macroscopic features of T. albobrunneum. Ikeda (2005) identified Matsushimeji as T. cf. striatum (Schaeff.) Quél. However, we regarded those descriptions as inappropriate for defining Japanese Matsushimeji. The habitats of Japanese T. albobrunneum populations are more diverse than those of European populations (Christensen \& Heilmann-Clausen, 2013), despite the shared host, Pinus. We examined specimens of T. ustale sensu Hongo (OMNH 1756, OMNH 1938, OMNH 1947, OMNH 3008, and OMNH 3606) and found that spore size and the presence of striate at the pileal margin matched the characters of T. albobrunneum.

\section{Discussion}

Kawamura (1925) first identified Kakishimeji as Tricholoma ustale Fr. Since then, Kakishimeji was consistently identified as T. ustale (Fr.) P. Kumm. (Ito, 1959; Imazeki \& Hongo, 1965, 1987; Katsumoto, 2010), and its closely related species, such as Matsushimeji, have been controversial. In this study, we conducted phylogenetic analyses of Japanese Tricholoma species and revealed four phylogenetic clades, which were morphologically identified at the species level. Of them, two are known species, and the other two are new species. Interestingly, true T. ustale was not found, suggesting that $T$. ustale is rare or absent in Japan.

Although T. albobrunneum specimens TUA-1 and TUA-2, both collected under P. pumila in northern Hokkaido, were regarded as the sister subclade to the other Japanese T. albobrunneum specimens based on Bayesian posterior probability in the ITS phylogeny (Fig. 1), they were positioned in the T. albobrunneum clade in the other five phylogenetic trees (including tef-1, atp6, and rpb2). Therefore, we regarded these two specimens as T. albobrunneum and the variation as infraspecific. However, Reschke et al. (2018) reported that Chinese T. albobrunneum is distinct from European T. albobrunneum based on the ITS phylogeny. We suggest that although species in the sect. Genuina in Tricholoma can be distinguished by ITS phylogeny, further phylogenetic analyses are needed to interpret the relationships with look-alike species complexes. 
Further investigations are necessary to clarify whether Japanese $T$. albobrunneum and Chinese T. albobrunneum reported by Reschke et al. (2018) are conspecific.

The newly described T. kakishimeji, a sister clade to T. pessundatum, has a wide range of host associations, i.e., both Pinaceae and Fagaceae. The confused identifications of Kakishimeji and Matsushimeji in Japan (Imazeki, 1942; Imazeki \& Hongo, 1957, 1965 , 1987; Ikeda, 2005) were caused in part by this fungal ecology. European T. pessundatum is limited to conifers, such as Picea, Pinus, and Abies (Christensen \& Heilmann-Clausen, 2013). However, because the conifer-associates of T. kakishimeji were mostly sampled in man-made stands in a forest site (TUA-75) or urban area (TUA-17, TUA-125), these preferred hosts might be Fagaceae. Bessette, Bessette, Roody, \& Trudell (2013) reported that North American $T$. pessundatum comprises two different groups distinguishable by spore size, i.e., 5.7-6.7 $\times 3.8-4.8 \mu \mathrm{m}$ around the Great Lakes and 4.8-5.7 $\times 2.9-3.8 \mu \mathrm{m}$ elsewhere, the latter matched European T. pessundatum. Japanese T. kakishimeji shows a similar spore size to that of European T. pessundatum. The T. pessundatum specimen collected in Yunnan Province in China (MB305071) reported by Reschke et al. (2018) positioned in the T. kakishimeji clade (Fig. 1).

The newly described T. kakishimejioides, sister clade to T. ustaloides Romagn., fruits under fagaceous trees. Japanese T. ustaloides was reported by Miyauchi $(1989,2010)$ as Kakishimeji-modoki and described by Ikeda (2005) as Nigashimeji. Nigashimeji has smaller spores than those of T. kakishimejioides and is much smaller compared with European T. ustaloides Romagn. In addition, $\mathrm{Ni}$ gashimeji is distributed in mixed forests of pine and oak, or oak forests, unlike T. kakishimejioides and T. ustaloides in Quercus forests, suggesting that Nigashimeji includes at least two species: $T$. kakishimejioides and T. albobrunneum. In fact, the Nigashimeji specimens identified by Y. Ikeda included those two species (Fig. 2). To date, no T. kakishimejioides sequence has been reported from China (Reschke et al., 2018). However, we suggest that $T$. kakishimejioides is probably present in China based on the geographic distribution of this fungal host. Recently, T. orientifulvum in the section Genuina was newly described from China (Xu, Cui \& Yang, 2020). This fungus is related to T. fulvum, T. ustaloides, T. kakishimejioides, and T. ustale. As it is macroscopically similar to $T$. fulvum, i.e., distinct yellowish gills, it is easily distinguished from $T$. kakishimejioides.

T. kakishimeji specimens TUA-19, TUA-67, and TUA-75 (TNS-F82064) contained ustalic acid (41.9-155.7 $\mu \mathrm{g} / \mathrm{g}$ in dry material) according to liquid chromatography-tandem mass spectrometry (LC-MS) analysis (Ito et al., 2021), while T. albobrunneum and T. ustaloides never contain ustalic acid and T. stans contains negligible levels (unpublished data). Therefore, stomach problems reportedly caused by T. ustale in Japan are in fact probably caused by T. kakishimeji.

\section{Disclosure}

The authors declare no conflicts of interest. All of the experiments in this study were performed in compliance with the current laws of Japan.

\section{Acknowledgements}

We thank Kentaro Hosaka (National Museum of Natural Science) and Daisuke Sakuma (Osaka Museum of Natural History), for loaning the herbarium specimens. We also thank the staff of the Research Center for Human Environmental Sciences, Shinshu University, for the DNA sequencing. This study was supported in part by JSPS KAKENHI Grant Number 15H01751 from Japan Society for the Promotion of Science.

\section{Reference}

Agerer, R. (ed). (1987-2008). Colour atlas of ectomycorrhizae, 1st-14th delivery. Schwäbisch Gmünd: Einhorn-Verlag.

Anderson, J. B., \& Stasovski, E. (1992). Molecular phylogeny of northern hemisphere species of Armillaria. Mycologia, 84, 505-516. https://doi.org/10.1080/0 0275514.1992.12026170

Bessette, A. E., Bessette, A. E., Roody, C. W., \& Trudell, S. A. (2013). Tricholoma of North America: A mushroom field guide. Austin: University of Texas Press.

Bidartondo, M. I., \& Bruns, T. D. (2002). Fine-level mycorrhizal specificity in the Monotropoideae (Ericaceae): specificity for fungal species groups. Molecular Ecology, 11, 557-569. https://doi.org/10.1046/j.0962-1083.2001.01443.x

Breitenbach, J., \& Kränzlin, F. (1991). Fungi of Switzerland, vol. 3. Lucerne: Mykologia.

Christensen, M., \& Heilmann-Clausen, J. (2013). The genus Tricholoma - Fungi of Northern Europe - vol. 4. Tilst, Denmark: Svampetryk.

Clémençon, H (2009). Methods for working with macrofungi: laboratory cultivation and preparation of larger fungi for light microscopy. Berlin: IHW Verlag.

Clémençon, H. (2012). Cytology and plectology of the Hymenomycetes, 2nd edn. Stuttgart: J. Cramer.

Duñabeitia, M. K., Hormilla, S., Salcedo, I., \& Peña, J. I. (1996). Ectomycorrhizae synthesized between Pinus radiata and eight fungi associated with Pinus spp. Mycologia, 88, 897-908. https://doi.org/10.1080/00275514.1996.12026730

Endo, N., Dokmai, P., Suwannasai, N., Phosri, C., Horimai, Y., Hirai, N., et al. (2015). Ectomycorrhization of Tricholoma matsutake with Abies veitchii and Tsuga diversifolia in the subalpine forests of Japan. Mycoscience, 56, 402-412. https:// doi.org/10.1016/j.myc.2014.12.004

Fries, E. M. (1818). Observationes mycologicae. Havniae: sumptibus G. Bonnier. https://doi.org/10.5962/bhl.title.112534

Gardes, M., \& Bruns, T. D. (1993). ITS primer with enhanced of specificity for basidiomycetes - application to the identification of mycorrhizae and rusts. Molecular Ecology, 2, 113-118. https://doi.org/10.1111/j.1365-294X.1993.tb00005.X

Grubisha, L. C., Levsen, N., Olson, M. S., \& Taylor, D. L. (2012). Intercontinental divergence in the Populus-associated ectomycorrhizal fungus, Tricholoma populinum. New Phytologist, 194, 548-560. https://doi.org/10.1111/j.1469-8137.2012.04066.x

Hagiwara, H. (2007). Color illustration of fungi described by Kumagusu Minakata (In Japanese). Tokyo: Shinchosha.

Halama, M., Ważny, R., Czosnykowska-Łukacka, M., \& Dobosz, T. (2016). Tricholoma ustaloides (Agaricales, Basidiomycota) in Poland. Polish Botanical Journal, 61, 173-180. https://doi.org/10.1515/pbj-2016-0007

Hayakawa, I., Watanabe, H., \& Kigoshi, H. (2008). Synthesis of ustalic acid, an inhibitor of $\mathrm{Na}^{+}, \mathrm{K}^{+}$-ATPase. Tetrahedron, 64, 5873-5877. https://doi.org/10.1016/j. tet.2008.04.051

Heilmann-Clausen, J., Christensen, M., Frøslev, T. G., \& Kjøller, R. (2017). Taxonomy of Tricholoma in northern Europe based on ITS sequence data and morphological characters. Persoonia, 38, 38-57. http://dx.doi.org/10.3767/003158517X693174

Henrion, B., Le Tacon, F., \& Martin, F. (1992). Rapid identification of genetic variation of ectomycorrhizal fungi by amplification of ribosomal RNA genes. New Phytologist, 122, 289-298.

Hiroe, I. (1949). Science of fungi (In Japanese). Osaka, Fuminsha.

Hofstetter, V., Clemençon, H., Vilgalys, R., \& Moncalvo, J. (2002). Phylogenetic analyses of the Lyophylleae (Agaricales, Basidiomycota) based on nuclear and mitochondrial rDNA sequences. Mycological Research, 106, 1043-1059.

Hongo, T. (1983). Notulae Mycologicae (18), Memoirs of the Faculty of Education, Shiga University, Natural Science, 11, 37-41. https://shiga-u.repo.nii.ac.jp/?action= pages_view_main\&active_action=repository_view_main_item_detail\&item id=1590\&item_no=1\&page_id=13\&block_id $=21$

Hongo, T. (ed.) (1994). Yama-kei field book on mushrooms (in Japanese). Tokyo: Yama-kei Publishers.

Ichioka, T. (1799). Shin-you-kin-pu (Colored illustration of mushrooms in the southern part of Shinshu area) (In Japanese). Own publication.

Ikeda, Y. (2005). Mushrooms and toadstools pictured book of Hokuriku (In Japanese). Kanazawa, Japan: Kakubundo.

Imai, S. (1938). Studies on the Agaricaceae of Hokkaido. I, Journal of the Faculty of Agriculture, Hokkaido Imperial University, 43, 1-178.

Imazeki, R. (1942). Colored illustrations of mushroom: How to collect and identification of mushrooms (In Japanese). Tokyo: Sanseido.

Imazeki, R., \& Hongo, T. (1957). Colored illustrations of fungi of Japan (In Japanese). Osaka: Hoikusha.

Imazeki, R., \& Hongo, T. (1965). Colored illustrations of fungi of Japan vol. II (In 
Japanese). Osaka: Hoikusha.

Imazeki, R., \& Hongo, T. (1987). Illustrations of mushrooms of Japan vol. I (In Japanese). Osaka: Hoikusha.

Imazeki, R., Hongo, T., \& Tubaki, K. (1970). Common fungi of Japan in color (In Japanese). Osaka: Hoikusha.

Ito, S. (1959). Mycological flora of Japan, Vol. 2, issue 5 (In Japanese). Sendai: Yokendo.

Ito, T., Nagai, H., Aoki, W., Yamada, A., Kawagishi, H., Fukaya, M and Konishi, H. (2021). Quantification of ustalic acid, a chemotaxonomic marker, in Tricholoma ustale using liquid chromatography-mass spectrometry. Journal of Natural Medicines, 75, 688-691. https://doi.org/10.1007/s11418-021-01496-Z

Katsumoto, K. (2010). List of fungi recorded in Japan (In Japanese). Tokyo: The Kanto Branch of the Mycological Society of Japan.

Kawamura, S. (1925). Illustrated Japanese fungi, 5th delivery (In Japanese). Tokyo: The Forest Experiment Station of the Department of Agriculture and Forestry.

Kawamura, S. (1929). The Japanese fungi (In Japanese). Tokyo: Daichi-shoin.

Kawamura, S. (1931). Edible fungi and poisonous fungi (In Japanese). Tokyo: Iwanami Shoten.

Kluting, K. L., Baroni, T. J., \& Bergemann, S. E. (2014). Toward a stable classification of genera within the Entolomataceae: a phylogenetic re-evaluation of the Rhodocybe-Clitopilus clade. Mycologia, 106, 1127-1142. https://doi.org/10.3852/13-270

Kretzer, A. M., \& Bruns, T. D. (1999). Use of atp6 in fungal phylogenetics: an example from the Boletales. Molecular Phylogenetics and Evolution, 13, 483-492. https://doi.org/10.1006/mpev.1999.0680

Kumar, S., Stecher, G., \& Tamura, K. (2016). MEGA7: molecular evolutionary genetics analysis version 7.0 for bigger datasets. Molecular Biology and Evolution, 33, 1870-1874. https://doi.org/10.1093/molbev/msw054

Kummer, P. (1871). Der Führer in die Pilzkunde: Anleitung zum methodischen, leichten und sichern Bestimmen der in Deutschland vorkommenden Pilze: mit Ausnahme der Schimmel- und allzu winzigen Schleim- und Kern-Pilzchen. Zerbst: Verlag von E. Luppe's Buchhandlung.

Larkin, M. A., Blackshields, G., Brown, N. P., Chenna, R., McGettigan, P. A., McWilliam, H., Valentin, F., Wallace, I. M., Wilm, A., Lopez, R., Thompson, J. D., Gibson T. J., \& Higgins, D. G. (2007). ClustalW and ClustalX version 2.0. Bioinformatics Applications Note, 23, 2947-2948. https://doi.org/10.1093/bioinformatics/btm404

Lefevre, C. K. (2002). Host associations of Tricholoma magnivelare, the American matsutake. PhD thesis, Oregon State University.

Matsuda, I., \& Hongo, T. (1962). Larger fungi in the lower temperate deciduous forest at the northern foot of Mt. Iide. The Journal of Japanese Botany, 37, 367-373. http://www.jjbotany.com/pdf/JJB_037_367-373.pdf

Miller S. L., Koo C. D., \& Molina R. (1991). Characterization of red alder ectomycorrhizae: a preface to monitoring belowground ecological responses. Canadian Journal of Botany, 69, 516-531. https://doi.org/10.1139/b91-071

Miyauchi, S. (1989). Mushrooms, and its culture (In Japanese). Mitsuke, Japan: Bunka Publisher.

Miyauchi, S. (2010). Mushrooms of Niigata Prefecture (In Japanese). Niigata: Niigata Nippou Jigyousha.

Murata, Y. (1978). New records of gill fungi from Hokkaido (1). Transactions of the Mycological Society of Japan, 19, 241-247.

Nagasawa, E. (2009). Poisonous fungi in Japan (In Japanese). Tokyo: Gakken.

Phillips, R. (1981). Mushrooms and other fungi of Great Britain and Europe. London: Pan Books.

Reschke, K., Popa, F., Yang, Z. L., \& Kost, G. (2018). Diversity and taxonomy of Tricholoma species from Yunnan, China, and notes on species from Europe and North America. Mycologia, 110, 1081-1109. https://doi.org/10.1080/00275514. 2018.1512295

Romagnesi, H. (1971). Petit atlas des champignons tome 2. Paris: Bordas.

Ronquist, F., Teslenko, M., van der Mark, P., Ayres, D. L., Darling, A., H€ohna, S., et al. (2012). MrBayes 3.2: Efficient Bayesian phylogenetic inference and model choice across a large model space. Systematic Biology, 61, 539-542. https://doi. org/10.1093/sysbio/sys029

Sano, Y., Sayama, K., Arimoto, Y., Inakuma, T., Kobayashi, K., Koshino, H., et al. (2002). Ustalic acid as a toxin and related compounds from the mushroom Tricholoma ustale. Chemical Communication, 13, 1384-1385. https://doi.org/10.1039/b202607d

Trappe J.M. (1962). Fungus associates of ectotrophic mycorrhizae. The Botanical Review, 28, 538-606. https://doi.org/10.1007/BF02868758

White, T. J., Bruns, T., Lee, S., \& Taylor, J. (1990). Amplification and direct sequencing of fungal ribosomal RNA genes for phylogenetics. In: Innis, M. A., Gelfand, D. H., Sninsky, J. J., \& White, T. J. (Eds), PCR Protocols: A guide to methods and applications (pp. 315-322). San Diego: Academic Press.

Xu, X., Cui, Y., Yang, Z. L. (2020). Two new species of Tricholoma sect. Genuina (Agaricales) from China. Phytotaxa, 443, 155-166. https://doi.org/10.11646/ phytotaxa.443.2.3
Yamada, A., Kanekawa, S., \& Ohmasa, M. (1999). Ectomycorrhiza formation of Tricholoma matsutake on Pinus densiflora. Mycoscience, 40, 193-198. https:// doi.org/10.1007/BF02464298

Yamada, A., Ogura, T., \& Ohmasa, M. (2001). Cultivation of mushrooms of edible ectomycorrhizal fungi associated with Pinus densiflora by in vitro mycorrhizal synthesis. II. Morphology of ectomycorrhizas in open-pot soil. Mycorrhiza, 11, 67-81. https://doi.org/10.1007/s005720000093

Yamada A., Kobayashi, H., Murata, H., Kalmis E., Kalyoncu, F., \& Fukuda, M. (2010). In vitro ectomycorrhizal specificity between the Asian red pine Pinus densiflora and Tricholoma matsutake and allied species from worldwide Pinaceae and Fagaceae forests. Mycorrhiza, 20, 333-339. https://doi.org/10.1007/ s00572-009-0286-6

Yamashita, M., \& Furukawa, H. (1993). Mushroom poisoning (In Japanese). Tokyo: Kyoritsu Shuppan. 